Original Research Paper

\title{
Characterization of Biochemical Compositions, Volatile Compounds and Sensory Profiles of Cabernet Sauvignon Wine in Successive Vintages (2008-2017)
}

\author{
${ }^{1+}$ Yufeng Ding, ${ }^{1,2+}$ Yanli Ma, ${ }^{1}$ Suping Li, ${ }^{1}$ Jingjing Liang, \\ ${ }^{1}$ Xiaoli Xi, ${ }^{1}$ Jie Wang, ${ }^{1}$ Jianfeng Sun, ${ }^{2}$ Haiyan Yu and ${ }^{2}$ Shuxian Guo \\ ${ }^{1}$ College of Food Science and Technology, Hebei Agricultural University, Hebei, 071000, China \\ ${ }^{2}$ Henan Key Laboratory of Industrial Microbial Resources and Fermentation Technology, \\ Nanyang Institute of Technology, Nanyang, 473000, China
}

Article history

Received: 20-06-2020

Revised: 26-07-2020

Accepted: $15-08-2020$

Corresponding Author:

Yanli Ma

College of Food Science and

Technology, Hebei

Agricultural University, Hebei,

071000, China

Email: xuexi_myl@sina.com

+ Contributed equally to this work and should be considered co-first authors.

\begin{abstract}
Cabernet Sauvignon grape is an emblematic cultivar of Huailai region, China, allowing obtaining wines accounts for a large proportion of national consumption. This work aimed to determine the differences in basic parameters, organic acids, phenolics, volatile compounds and sensory profiles of Cabernet Sauvignon wines of successive vintages (2008-2017). The total organic acids content ranged from 7.03 to $42.33 \mathrm{~g} \mathrm{~L}^{-1}$, with higher concentration determined in 2008 and 2009 and the level of tartaric acid in latest vintages (2015-2017) was higher than earlier vintages (2008-2014). For phenolics, the total content ranged from 2370 to $4430 \mathrm{mg} \mathrm{L}^{-1}$ and 2017 vintage showed the highest concentration due to higher content of benzoic, salicylic and vanillic acid. Regarding volatile compounds, esters were the most abundant compounds ranged from 3997.77 to $6279.00 \mu \mathrm{g} \mathrm{L}^{-1}$. The distribution of date was accumulated three groups according to principal component analysis based on volatile compounds and vintages: The earlier vintages of 2008 and 2009, latest vintage of 2017 and the vintage in the middle from 2010 to 2016. 2-hexenoic acid, ethyl ester, n-heptanol, bornyl acetate, ethyl isopentyl succinate and terpinen-4-ol were the main compounds responsible for classification according to 2017 vintage ( $\mathrm{r}_{\mathrm{PC} 1}>0.7$ ). Regarding the wine of 2008 and 2009, lots of esters including ethyl 3-phenylpropionate, ethyl laurate, ethyl nonanoate, ethyl 2methylbutyrate and ethyl isovalerate seemed to be the most discriminant compounds. The observed differences may lay a research foundation for harvest differentiation and provide reference regarding the choice and storage of Cabernet Sauvignon wines. Furthermore, the obtained data could provide some useful information of the storage effect to the wines producer. This study provided consumers with comprehensive chemical indicators of wine quality and the mechanism of component transformation such as phenolics, which were expected to study during storage.
\end{abstract}

Keywords: Cabernet Sauvignon Wine, Vintage, Phenolics, Volatile Compounds, Principal Component Analysis

\section{Introduction}

Grapes are one of the most productive fruits in the world, approximately $70 \%$ of which is used for producing wine (Aubert and Chalot, 2018). Wine has become a broadly beverage and unquestionably more and more wine grape-growing regions have been developed in China. According to the National Bureau of Statistics, the wine production is about 7.9 million $\mathrm{L}$ in 2019. Over $69 \%$ of wine is produced in Huailai County, Hebei province. There are about 30 wineries in this area, which account for a large proportion of Chinese wine market. Cabernet Sauvignon (Vitis vinifera L.), as the most popular introduced variety, is considered the 
emblematic cultivar of Huailai. It could well adapt to the agricultural conditions of Huailai area (an altitude of 450-600 $\mathrm{m}$ and semi-arid climate) and allow obtaining wines with a distinctive style which are resulting from the influence of various factors (climate, vineyard, grape maturity, techniques, vintages, etc.) (Li et al., 2011).

Epidemiological and clinical studies have shown that moderate drinking of wine could reduce the incidence of coronary heart diseases and atherosclerosis (Artero et al., 2015). This effect may due to antioxidant capacity of phenolic compounds in wine, especially red wine. Furthermore, these compounds play an important role on the astringency and color of wine. Phenolic compounds were reported to involve two main groups: Flavonoids (anthocyanins, flavanols and dihydroflavonols) and nonflavonoids (hydroxybenzoic, hydroxycinnamic acids and their derivatives, stilbenes and phenolic alcohols) (Fanzone et al., 2012). The content of phenolic compounds in wine depends on initial composition (climatic conditions, soil and techniques) and storage condition (time, temperature, humidity and ageing container). Researches have shown that the copigmentation, condensation and polymerisation of polyphenols could produce ellagitannins, which accelerated the condensation between flavanols or tannins with anthocyanins and these reactions were considered to be responsible for the color change during storage process (Dumitriu et al., 2017). Moreover, the phenolics concentration of wine from different harvests are different. Previous reports which investigated Verdelho wines from six successive vintages (2010-2015) have shown epicatechin, gallic acid and kaempferol-3-O-rutinoside were largely responsible for Verdelho wines classification according to vintage (Perestrelo et al., 2020) and it was reported that the aged wine had higher content of polymeric pigments, lower content of anthocyanins and other phenolics than younger wine from different harvests (Burin et al., 2011; McRae et al., 2012).

Apart from the phenolic composition, the cooccurring organic compositions such as organic acids and volatile compounds determine the bioactive and nutritional quality. Organic acid, an important flavour compounds in wine, regulate the acid-base balance of wine and affect the sensory characteristics and biological stability. For example, tartaric acid is particularly associated with $\mathrm{pH}$ value, color, oxidation characteristics, microbial stability as well as promoting ageing potentiality of wine (Sartor et al., 2019). Additionally, the relationship between volatile compounds and sensory evaluation of wines is a critical topic in wine classification. Wine aromas mainly derive from the metabolites of yeast and amino acid metabolish (Cai et al., 2014). Apart from the influence of grapevine and varietal, several researches focused on the effect of ageing on aroma. Someone have studied the evolution of aroma compounds by different ageing time and ageing techniques such as oak barrel, oak chip, bottle and stainless-steel tanks under micro-oxygenation circumstance (Nevares and del Álamo, 2008; De Esteban et al., 2019; Canas et al., 2019). Sensory evaluation based on trained panel plays a primary role in consumer satisfaction, since it can segment the consumers according to set of sensory attributes. Furthermore, sensory analysis techniques are increasingly used as a tool to characterize wines' differentiation (Schelezki et al., 2018).

There is a lack of studies on individualized chemical compositions in different vintages of Cabernet Sauvignon wines in Huailai area. Thus, the aim of this study was to compare the composition and content of phenolics and organic acids of wines obtained from successive vintages (2008-2017) in Huailai region by high performance liquid chromatograph. Furthermore, volatile compositions and sensory profiles were also established. Finally, Principal Components Analysis (PCA) was used for classification of volatile compounds related to vintage. This study provided an interesting insight on the impact of vintages in final quality and therefore in its market value.

\section{Materials and Methods}

\section{Chemicals}

The following chemicals were obtained from SigmaAldrich: Gallic acid (CAS: 149-91-7), (+)-catechin (CAS: 18829-70-4), vanillic acid (CAS: 121-34-6), ferulic acid (CAS: 1135-24-6), guaiacol (CAS: 90-05-1), benzoic acid (65-85-0), salicylic acid (69-72-7), quercetin (CAS: 117-39-5), tartaric acid (CAS: 133-379), lactic acid (CAS: 50-21-5), malic acid (CAS: 691515-7), succinic acid (CAS: 110-15-6), oxalic acid (CAS: 144-62-7) and citric acid (CAS: 77-92-9) (>98\% purity).

\section{Sample Collection and Vinification}

Cabernet Sauvignon wines (2008-2017) were provided by a noble estate in Huailai, Hebei, China. Cabernet Sauvignon grapes were collected from the same vineyard at their maturity state and in a good sanitary stage, across ten successive harvests. The process was performed based on the currently stable and mature technologies employed in Cabernet Sauvignon wine production. Selected grapes were initially destemmed and crushed. Then, the must was treated with sulfurous acid about $50 \mathrm{mg} \mathrm{L^{-1 }}$. Meantime, pectinase (LAFFORT, France) was added to the must $\left(3 \mathrm{~g} \mathrm{Kg}^{-1}\right)$. After one day of clarification, $200 \mathrm{mg} \mathrm{L}^{-1}$ dried active yeast (Saccharomyces cerevisiae ZYMAFLORE F15, LAFFORT, France) was added to the must to conduct the alcoholic fermentation about ten days and the room 
temperature was controlled at $15^{\circ} \mathrm{C}$ during this period. Afterwards the alcoholic fermentation, $10 \mathrm{mg} \mathrm{Kg}^{-1}$ lactic acid bacteria (LACTOENOS 450PREAC, LAFFORT, France) was added for Malolactic Fermentation (MLF) about seven days. Then the wine was racked off gross lees, $3 \mathrm{~g} \mathrm{Kg}^{-1}$ pectinase and $50 \mathrm{mg} \mathrm{L}^{-1}$ sulfurous acid were added stabilizing for 25 days. Before bottling, the final free $\mathrm{SO}_{2}$ was required to be adjusted to a total content of $0.8 \mathrm{mg} \mathrm{L}^{-1}$. Finally, wines were filtered through a $0.8 \mu \mathrm{m}$ membrane and then bottled in $750 \mathrm{~mL}$ glass bottle with screw-cap.

A total of 30 samples from Huailai area, three wine samples per year, produced in ten successive vintages. In order to obtain representative samples per year, ten successive vintages (2008-2017) wines were collected from three independent tanks with same technological treatment. The collected samples from different vintages were analyzed at last.

\section{Determination of Basic Parameters}

pH was determined by using a pH meter (Model 340, Mettler Toledo GmbH, Schwerzenbach, Switzerland), whereas total acidity was determined by diluting $10 \mathrm{~mL}$ wine in $50 \mathrm{~mL}$ deionised water and titrating to $\mathrm{pH} 8.2$ with $0.05 \mathrm{~mol} \mathrm{~L}^{-1} \mathrm{NaOH}$ (expressed as $\mathrm{g}$ of tartaric $\mathrm{acid} / \mathrm{L}$ ) with continuous stirring. Alcohol content was measured by using a hydrometer (SHUFENG, Zhengzhou, China), with result as the volume percent (\% vol) (Samoticha et al., 2017). Measure $100 \mathrm{~mL}$ sample with volumetric flask into $500 \mathrm{~mL}$ distillation flask. Then wash the volumetric flask with $50 \mathrm{~mL}$ deionized water and transfer the washing solution to the flask. The distilled solution was collected into a $100 \mathrm{~mL}$ volumetric cylinder. After $10 \mathrm{~min}$ of standing, the alcohol content was measured by using a hydrometer. Dry extract content was determined by pyknometer method according to the Office International (GB/T 15038-2006, 2006). Firstly, measure the density of the sample after evaporation of ethanol. The measured density values could correspond to the total extract content. The dry extract was expressed as the total extract content minus the total sugar content. Total sugar was determined by using 3,5-Di-Nitrosalicylic reagent (DNS) reported by (Miller, 1959). Briefly, $1 \mathrm{~mL}$ sample diluted with distilled water was mixed with $0.75 \mathrm{~mL} 6 \mathrm{~mol} \mathrm{~L}^{-1} \mathrm{HCl}$. The mixture was incubated for $20 \mathrm{~min}$ at a boiling water bath. When the mixture cooled to room temperature, it was added with $1 \mathrm{~mL} 6 \mathrm{~mol} \mathrm{~L}^{-1} \mathrm{NaOH}$ and $1.5 \mathrm{~mL}$ DNS and then placed into a boiling water bath for $5 \mathrm{~min}$. The reaction solution was diluted to $10 \mathrm{~mL}$ with deionized water finally and measured at $550 \mathrm{~nm}$ using a UV/Vis spectrophotometer (Qinghua, Shanghai, China). Total Phenolic (TP) content was determined by FolinCiocalteu colorimetry reported by (Folin and Denis, 1915). One $\mathrm{mL}$ of supernatant, previously diluted 10 - fold with deionized water, was mixed with deionized water $(6 \mathrm{~mL})$ and Folin-Ciocalteu reagent $(0.5 \mathrm{~mL})$. Next, the mixture was added with $1.5 \mathrm{~mL} 17 \%$ sodium carbonate $\left(\mathrm{Na}_{2} \mathrm{CO}_{3}\right)$ quickly. The reaction solutions were diluted to $10 \mathrm{~mL}$ with deionized water, incubated at room temperature for $2 \mathrm{~h}$ and then measured at $765 \mathrm{~nm}$ using a UV/Vis spectrophotometer (Qinghua, Shanghai, China). Methanol content was analyzed by Gas Chromatography (GC) using the Agilent 7890B GC equipped with a flame ionizing detector $\left(\mathrm{H}_{2} ; 40 \mathrm{~mL}\right.$ $\mathrm{min}^{-1}$ and air: $400 \mathrm{~mL} \mathrm{~min}^{-1}$ ) and a CP9205 VFWAXms capillary column $(30 \mathrm{~m} \times 0.25 \mathrm{~mm}$; J\&W Science, Folsom, CA, USA) reported by (Wang et al., 2004) with minor modifications. Flow rate of carrier gas

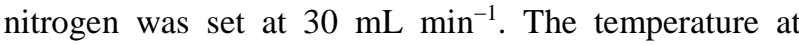
injector port and detector was set at 200 and $220^{\circ} \mathrm{C}$, respectively. Split stream sampling was applied and split ratio was 5:1 (about $1 \mu \mathrm{L}$ for each injector). The oven temperature program was as follow: $60^{\circ} \mathrm{C}$ for $2 \mathrm{~min}$, increased to $70^{\circ} \mathrm{C}$ at the rate of $5^{\circ} \mathrm{C} \mathrm{min}^{-1}$, then raised to $100^{\circ} \mathrm{C}$ at $5^{\circ} \mathrm{C} \mathrm{min}^{-1}$ and maintained for $1 \mathrm{~min}$. The Soluble Solid Content (SSC) of wine was analysed by a digital refractometer (Atago Co., Ltd., Tokyo, Japan) and the results were expressed in ${ }^{\circ}$ Brix. The color of wine samples was analysed by an A5 Chroma-Meter (Minolta CR300, Osaka, Japan) referring to CIELAB color space. The total colour difference $\left(\Delta \mathrm{E}^{*}\right)$ was obtained from the following formula: $\Delta \mathrm{E}^{*}=\left[\left(\Delta \mathrm{L}^{*}\right)^{2}+\left(\Delta \mathrm{a}^{*}\right)^{2}+\left(\Delta \mathrm{b}^{*}\right)^{2}\right]^{1 / 2}$, where $\Delta \mathrm{L}=\mathrm{L}_{\text {standard }}-\mathrm{L}_{\text {sample }}, \Delta \mathrm{a}=\mathrm{L}_{\text {standard }}-\mathrm{L}_{\text {sample }}$ and $\Delta \mathrm{b}=$ $b_{\text {standard }}-b_{\text {sample }}\left(\right.$ Erkan et al., 2020). The L*, a* and $b^{*}$ values of a white standard tile utilized as reference were 97.31, 4.95 and -3.26 , respectively. Wine Color Intensity (CI) was expressed as the sum of 420, 520 and 620 Abs and hue as 420/520 Abs according to the method reported by (Glories, 1984).

\section{Determination of Organic Acids}

The organic acids were extracted following the methods reported by (Han et al., 2019) with modifications. Briefly, $5 \mathrm{~mL}$ samples were mixed with $\mathrm{K}_{4}\left[\mathrm{Fe}(\mathrm{CN})_{6}\right] \cdot 3 \mathrm{H}_{2} \mathrm{O}(2 \mathrm{~mL}, 10.6 \%)$ and $\mathrm{ZnSO}_{4}(2 \mathrm{~mL}$, $30 \%)$. Then, the mixture was diluted with pure water to $100 \mathrm{~mL}$. After precipitation for $15 \mathrm{~min}$, the collected supernatant was centrifuged at $6500 \times \mathrm{g}$ at $4{ }^{\circ} \mathrm{C}$ for 15 min. Finally, centrifuged solution was successively filtered through C-18 column and $0.45 \mu \mathrm{m}$ filtration (Millipore, Bedford, MA, USA) prior to the analysis.

The identification and quantification of individual organic acids (tartaric acid, malic acid, lactic acid, acetic acid, succinic acid, oxalic acid and pyruvic acid) in wine samples from different vintages were performed by High Performance Liquid Chromatography (HPLC). The HPLC system was equipped with a Waters 1525 Binary HPLC pump, Waters 2707 autosampler injector, CTO20AC oven, DGU-20A5R degasser and Waters 2489 
ultraviolet-visible detector. All organic acids were separated using a C18 column $(3.9 \times 150 \mathrm{~mm}, 5 \mu \mathrm{m}$, Agilent) with column oven temperature of $30^{\circ} \mathrm{C}$ and the detector was set at $210 \mathrm{~nm}$. The mobile phase was 0.02 mol L ${ }^{-1} \mathrm{NaH}_{2} \mathrm{PO}_{4}$ and the $\mathrm{pH}$ was adjusted to 2.7 with phosphoric acid. The flow rate was $1 \mathrm{~mL} \min ^{-1}$ and total run time was $20 \mathrm{~min}$. All samples injected into the chromatograph system was $10 \mu \mathrm{L}$.

\section{Determination of Phenolics}

Phenolics were identified and quantified by HighPerformance Liquid Chromatography (HPLC) using a C18 column $(3.9 \times 150 \mathrm{~mm}, 5 \mu \mathrm{m}$, Agilent $)$ as described previously. The procedure used to obtain phenolics was performed according to the method of (Katalinić et al., 2010). The column oven temperature was kept at $30^{\circ} \mathrm{C}$. The mobile phases consisted of solvents A (water/acetic acid, 98:2) and B (acetonitrile). The gradient elution was as follows: $0 \mathrm{~min}, 97 \% \mathrm{~A}$ and $3 \%$ $\mathrm{B} ; 5 \mathrm{~min}, 90 \% \mathrm{~A}$ and $10 \% \mathrm{~B} ; 15 \mathrm{~min}, 85 \% \mathrm{~A}$ and $15 \%$ $\mathrm{B} ; 25 \mathrm{~min}, 75 \% \mathrm{~A}$ and $25 \% \mathrm{~B} ; 35 \mathrm{~min}, 70 \% \mathrm{~A}$ and $30 \%$ $\mathrm{B}$; and $40 \mathrm{~min}, 97 \% \mathrm{~A}$ and $3 \% \mathrm{~B}$. The flow rate was set at $1.0 \mathrm{~mL} \mathrm{~min}{ }^{-1}$. The detector was set at $280 \mathrm{~nm}$. For the analysis, $10 \mu \mathrm{L}$ of sample was injected into the chromatograph system.

\section{Determination of Volatile Compounds}

Sample analysis of volatile compounds were conducted through headspace Solid-Phase Microextraction (SPEM) and GC-MS according to the method of (Aubert and Chalot, 2018) with minor modifications. $7.5 \mathrm{~mL}$ wine sample, $1 \mathrm{~g} \mathrm{NaCl}$ and $25 \mu \mathrm{L} 3$-octanol were added into a $20 \mathrm{~mL}$ glass vial. Then the vial was heated in a $40^{\circ} \mathrm{C}$ water bath. After $15 \mathrm{~min}$ pre-equilibrating, a polydimethylsiloxane fibre $(1 \mathrm{~cm}, 50 / 30 \mu \mathrm{m}$ thickness $)$ was placed in the vial to extract for $40 \mathrm{~min}$. Finally, the solid-phase micro-extraction fibre was immediately inserted into the GC injector to perform extractions of thermal desorption about $6 \mathrm{~min}$. Each wine sample was extracted in triplicate.

Volatile compounds analysis was performed on a HPINNOWAX capillary column $(60 \mathrm{~m} \times 0.25 \mathrm{~mm}$; J\&W Science, Folsom, CA, USA) using the Agilent 7890B GC equipped with an Agilent 5975 MS. The oven temperature program was as follow: $50^{\circ} \mathrm{C}$ for $2 \mathrm{~min}$, increased to $80^{\circ} \mathrm{C}$ at the rate of $3^{\circ} \mathrm{C} \mathrm{min}^{-1}$, then raised to $230^{\circ} \mathrm{C}$ at $5^{\circ} \mathrm{C} \mathrm{min}^{-1}$, then kept $230^{\circ} \mathrm{C}$ for $6 \mathrm{~min}$. The injector temperature was $240^{\circ} \mathrm{C}$. The helium was used as carrier gas $\left(1.45 \mathrm{~mL} \mathrm{~min}{ }^{-1}\right)$. The temperature of the ion source and $\mathrm{MS}$ transfer line were $240^{\circ} \mathrm{C}$ and $250^{\circ} \mathrm{C}$, respectively. The electron energy was $70 \mathrm{eV}$ with the mass range from 33 to $550 \mathrm{~m} / \mathrm{z}$.

The National Institute of Standards and Technology mass spectrum library and retention times from authentic standards were used to quantify the volatile compounds. For these compounds, semi-quantitative analysis was carried out and the concentration was expressed as equivalents of the inserted internal standard (3-octanol). In the absence of pure reference, the calibration map was consulted for chemically similar compounds (Xu et al., 2015).

\section{Sensory Evaluation}

The wine samples from ten successive vintages (2008-2017) were tasted by nine specially trained panel (five men and four women) from the Hebei Agricultural University. All of them had participated in wine descriptive sensory analysis training programs and they had abundant experiences in tasting Cabernet Sauvignon wines with different characteristics. The commonly-used 10 odor categories of wines including fruity (apple and south pear), floral (rose and violet), nuts (almond and walnut), spicy (spicy and liquorice), sweet (candies and roasted potato), acidic (orange and passion fruit), fatty (white meat), soil-like (soil and moldy), woody (oak), toasted (smoke and coffee beans) and vegetable aromas (grass and green pepper) were selected. In the sensory experiments, $30-50 \mathrm{~mL}$ wine was placed in a random coded wine glass at controlled room temperature $\left(20^{\circ} \mathrm{C}\right)$ and presented to the panelists. The panelists were asked to avoid shaking the wine glass for the initial 3-5 s. Afterward, they were asked to shake the wine glass and smell the wine for 3-5 s. The samples were evaluated in duplicate. Particularly, intensities of ten sensorial descriptors were scored on a 15-point scale (0 not perceptible, 1-5 weak, 6-10 medium, 1115 strong, 15 very strong). For each descriptor, the average score given by each member was calculated. Tukey's Honestly Significant Difference (HSD) test was used for statistical evaluation.

\section{Statistical Analysis}

Statistical analysis was performed with SPSS 20.00 (Inc., Chicago, IL, USA). One-way ANOVA by Duncan's test was applied at the significance level of 5\% to examine the effect of harvests on different chemical components. All variables followed the normal distribution. Principal Component Analysis (PCA) was performed for classification of volatile compounds related to vintage using SIMCA 14.1 (Umetrics, Sweden).

\section{Results and Discussion}

\section{Physicochemical Characterization of Wines}

The general analytical parameters evaluated of wines including total sugar, total acid, dry extract, $\mathrm{pH}$, methanol and SSC were listed in Table 1. Among all 
the vintages analysed, Cabernet Sauvignon wine of the vintage 2017 showed the highest value of total sugar $\left(1.36 \mathrm{~g} \mathrm{~L}^{-1}\right)$, dry extract $\left(78.69 \mathrm{~g} \mathrm{~L}^{-1}\right)$ and ${ }^{\circ}$ Brix (9.10), however, the dry extract content of 2013 was similar to 2017. These parameters showed different statistical differences in different vintage wines, which might be attributed to grape differences and climate factors. The alcohol concentration of all samples was between 12 and $14 \%$, which was in accordance with other red wine in the range of 12 to $15 \%$ (Fanzone et al., 2012). It is important to note that the wine of 2010 and 2011 vintage showed inferior value of total acid but higher value of $\mathrm{pH}$ than the rest vintages. The content of total acid was in agreement with the range of 5.26 to 8.45 reported in the literature (Fanzone et al., 2012; Jiang et al., 2013). In all studied wines, the methanol content was below $400 \mathrm{mg} \mathrm{L}^{-1}$ within the legal limit (GB/T 15038-2006, 2006).

The color parameters evaluated by CIELAB coordinates, $\mathrm{L}^{*}, \mathrm{a}^{*}, \mathrm{~b}^{*}, \mathrm{CI}$ and hue were presented in Table 1 . The $\mathrm{L}^{*}$-axis represented the lightness ranging from 0 (black) to 100 (white). Wines of 2008, 2009 and 2010 vintages showed significantly higher value of $\mathrm{L}^{*}$ $(p<0.05)$ than the other vintages. The coordinate of $a^{*}$ explained the direction towards redness-greenness, whereas $b^{*}$ represented yellowness-blueness. 2008 and 2009 wines with higher a* values were redder than other wines from other harvests, moreover, wines of these two vintages presented typical characteristic of ageing wines (dark red). This phenomenon can be supported by long storage in bottle. Meanwhile, parameter $b^{*}$ showed that wines of 2008, 2009, 2010 and 2011 were bluer than other investigated vintages. Hernanz et al. (2009) reported an increase in a* and $b^{*}$ values after 12 months of storage of Spanish wine. There are some consistent results with previous findings due to the differences between samples. Higher of colour difference $\left(\Delta \mathrm{E}^{*}\right)$ were observed in vintages of 2013 and 2016, followed by 2012. Insignificant differences $(\mathrm{p}>0.05)$ were observed in vintages of 2008 , 2009, 2014, 2015 and 2017. The CI of Cabernet Sauvignon wines was in the range of 6.69-9.88. The wines of different harvest year had no significant effect on hue value, which fluctuated around 1 .

\section{Organic Acids of Wines}

Table 2 showed the concentration of eight organic acids among samples of ten successive harvests from 2008-2017. The total organic acids content ranged from 5.95 to $12.01 \mathrm{~g} \mathrm{~L}^{-1}$, with the significant higher $(\mathrm{p}<0.05)$ concentration determined in 2016 vintage, followed by 2015 vintage and insignificant changes were observed between the vintage from 2010 to 2013. The average concentrations of these components were similar to those found in other studies of red wines (Sartor et al., 2019; Colangelo et al., 2018). Malic acid, lactic acid and tartaric acid were richer than other compounds among samples, which was consistent with the red wine in different countries observed in this literature (Robles et al., 2019). Significantly higher malic acid content was observed in vintages of 2010 and 2016. Nevertheless, the vintage of 2011 showed the highest level of lactic acid that might indicate that the initial malic acid content of grapes in this harvest year was high. The level of tartaric acid in the vintages of 2015, 2016 and 2017 were higher than those in the vintages of 2008-2014. This is because part of tartaric acid and ethanol can be esterified during the storage process (Yang et al., 2020). Therefore, vintage showed statistically significant effect on the individual organic acid. Citric acid was not detected in all samples, since it could be degraded by lactic acid bacteria during MLF. These results are consistent with the literature (Sartor et al., 2019). Acetic acid was related to the degradation of citric acid by Lactobacillus and its content ranged from 0.37 to $1.08 \mathrm{~g} \mathrm{~L}^{-1}$ Succinic acid appear as a consequence from alcohol fermentation and insignificant changes of succinic acid were observed of different wines of ten successive harvests, since the difference was only $0.13 \mathrm{~g} \mathrm{~L}^{-1}$. This can be due to specific yeast strains, because different strains influence the organic acid composition of wines (Chidi et al., 2015). The contents of oxalic acid and pyruvic acid accounted for a small proportion of total organic acid.

Table 1: Physicochemical properties of Cabernet Sauvignon wines of ten successive vintages

\begin{tabular}{|c|c|c|c|c|c|c|c|c|c|c|c|c|c|c|}
\hline \multirow[b]{2}{*}{ Vintage } & \multirow[b]{2}{*}{$\begin{array}{l}\text { Total sugar } \\
\left(\mathrm{g} \mathrm{L}^{-1}\right)\end{array}$} & \multirow[b]{2}{*}{$\begin{array}{l}\text { Total acidity } \\
\left(\mathrm{g} \mathrm{L}^{-1}\right)\end{array}$} & \multirow[b]{2}{*}{$\begin{array}{l}\text { Dry extract } \\
\left(\mathrm{g} \mathrm{L}^{-1}\right)\end{array}$} & \multirow[b]{2}{*}{$\begin{array}{l}\text { Ethanol } \\
(\% \mathrm{vol})\end{array}$} & \multirow[b]{2}{*}{$\mathrm{pH}$} & \multirow[b]{2}{*}{$\begin{array}{l}\text { Methanol } \\
\left(\mathrm{mg} \mathrm{L}^{-1}\right)\end{array}$} & \multirow[b]{2}{*}{${ }^{\circ}$ Brix } & \multirow{2}{*}{$\begin{array}{l}\mathrm{TP} \\
\left(\mathrm{mg} \mathrm{mL}^{-1}\right)\end{array}$} & \multicolumn{6}{|l|}{ Color } \\
\hline & & & & & & & & & $\mathrm{L}^{*}$ & $a^{*}$ & $\mathrm{~b}^{*}$ & $\triangle \mathrm{E}$ & CI & Hue \\
\hline 2008 & $0.85 \pm 0.03^{\mathrm{d}}$ & $8.43 \pm 0.04^{\mathrm{a}}$ & $72.48 \pm 0.67^{\mathrm{h}}$ & $12.33 \pm 0.30^{\mathrm{d}}$ & $3.34 \pm 0.02^{\mathrm{e}}$ & $380.41 \pm 13.62^{\text {bcd }}$ & $8.20 \pm 0.05^{\mathrm{e}}$ & $2.61 \pm 0.05^{\mathrm{de}}$ & $24.45 \pm 0.11^{\mathrm{a}}$ & $4.25 \pm 0.08^{\mathrm{a}}$ & $0.26 \pm 0.09^{\mathrm{b}}$ & $73.16 \pm 0.09^{\mathrm{e}}$ & $7.15 \pm 0.02^{\text {cd }}$ & $1.15 \pm 0.01^{\mathrm{ab}}$ \\
\hline 2009 & $0.95 \pm 0.02^{\mathrm{c}}$ & $6.01 \pm 0.16^{\mathrm{g}}$ & $76.28 \pm 0.96^{\mathrm{d}}$ & $14.30 \pm 0.17^{\mathrm{ab}}$ & $3.45 \pm 0.02^{\mathrm{c}}$ & $305.68 \pm 17.02^{\mathrm{b}}$ & $8.30 \pm 0.06^{\mathrm{d}}$ & $2.75 \pm 0.03^{\mathrm{d}}$ & $24.04 \pm 0.31^{\mathrm{b}}$ & $4.12 \pm 0.04^{\mathrm{b}}$ & $0.14 \pm 0.39^{\mathrm{bc}}$ & $73.34 \pm 0.33^{\mathrm{e}}$ & $8.63 \pm 0.18^{\mathrm{b}}$ & $1.01 \pm 0.04^{\mathrm{abc}}$ \\
\hline 2010 & $0.79 \pm 0.02^{\mathrm{e}}$ & $5.26 \pm 0.04^{\mathrm{i}}$ & $73.04 \pm 0.38^{\mathrm{f}}$ & $14.20 \pm 0.20^{\mathrm{ab}}$ & $3.58 \pm 0.01^{\mathrm{a}}$ & $362.35 \pm 21.36^{\mathrm{a}}$ & $8.30 \pm 0.00^{\mathrm{de}}$ & $2.42 \pm 0.15^{\mathrm{ef}}$ & $24.49 \pm 0.11^{\mathrm{a}}$ & $3.75 \pm 0.10^{\mathrm{d}}$ & $0.52 \pm 0.07^{\mathrm{a}}$ & $72.91 \pm 0.10^{\mathrm{f}}$ & $7.34 \pm 0.14^{\mathrm{c}}$ & $1.28 \pm 0.15^{\mathrm{a}}$ \\
\hline 2011 & $0.75 \pm 0.03^{\mathrm{e}}$ & $5.90 \pm 0.03^{\mathrm{h}}$ & $73.08 \pm 0.35^{\mathrm{f}}$ & $14.40 \pm 0.20^{\mathrm{a}}$ & $3.62 \pm 0.02^{\mathrm{a}}$ & $376.68 \pm 29.52^{\text {bcd. }}$ & $7.80 \pm 0.00^{\mathrm{g}}$ & $2.08 \pm 0.13^{\mathrm{g}}$ & $23.82 \pm 0.06^{\mathrm{c}}$ & $3.87 \pm 0.09^{\mathrm{c}}$ & $0.22 \pm 0.02^{\mathrm{b}}$ & $73.57 \pm 0.07^{\mathrm{d}}$ & $6.69 \pm 0.06^{\mathrm{d}}$ & $1.18 \pm 0.02^{\mathrm{ab}}$ \\
\hline 2012 & $0.87 \pm 0.03^{\mathrm{d}}$ & $7.06 \pm 0.03^{\mathrm{d}}$ & $72.96 \pm 0.63^{g}$ & $14.33 \pm 0.30^{\mathrm{ab}}$ & $3.40 \pm 0.02^{\mathrm{d}}$ & $285.54 \pm 13.15^{\mathrm{d}}$ & $8.00 \pm 0.00^{\mathrm{f}}$ & $2.37 \pm 0.03^{f}$ & $23.25 \pm 0.03^{\mathrm{d}}$ & $3.29 \pm 0.02^{\mathrm{e}}$ & $-0.16 \pm 0.09^{\mathrm{d}}$ & $74.13 \pm 0.03^{\mathrm{b}}$ & $8.32 \pm 0.27^{\mathrm{b}}$ & $1.11 \pm 0.07^{\mathrm{ab}}$ \\
\hline 2013 & $0.93 \pm 0.01^{\mathrm{c}}$ & $6.63 \pm 0.05^{\mathrm{e}}$ & $78.11 \pm 0.56^{\mathrm{b}}$ & $14.27 \pm 0.30^{\mathrm{ab}}$ & $3.43 \pm 0.02^{\mathrm{cd}}$ & $365.34 \pm 50.42^{\mathrm{b}}$ & $8.90 \pm 0.06^{\mathrm{b}}$ & $3.74 \pm 0.08^{\mathrm{b}}$ & $23.84 \pm 0.05^{\mathrm{e}}$ & $2.93 \pm 0.08^{g}$ & $-0.44 \pm 0.10^{\mathrm{e}}$ & $74.53 \pm 0.05^{\mathrm{a}}$ & $9.73 \pm 0.72^{\mathrm{a}}$ & $0.98 \pm 0.04^{\mathrm{abc}}$ \\
\hline 2014 & $1.03 \pm 0.02^{\mathrm{b}}$ & $6.20 \pm 0.05^{\mathrm{f}}$ & $76.41 \pm 0.86^{\mathrm{c}}$ & $14.30 \pm 0.10^{\mathrm{ab}}$ & $3.50 \pm 0.05^{\mathrm{b}}$ & $305.83 \pm 29.60^{\mathrm{cd}}$ & $8.40 \pm 0.06^{\mathrm{d}}$ & $3.42 \pm 0.04^{\mathrm{c}}$ & $23.47 \pm 0.05^{\mathrm{d}}$ & $3.00 \pm 0.02^{\mathrm{fg}}$ & $-0.85 \pm 0.06^{\mathrm{T}}$ & $73.89 \pm 0.05^{\mathrm{c}}$ & $9.31 \pm 0.51^{\mathrm{a}}$ & $0.76 \pm 0.48^{\mathrm{c}}$ \\
\hline 2015 & $0.92 \pm 0.01^{\mathrm{c}}$ & $8.15 \pm 0.04^{\mathrm{b}}$ & $70.52 \pm 0.58^{\mathrm{i}}$ & $13.20 \pm 0.10^{c}$ & $3.25 \pm 0.02^{\mathrm{f}}$ & $378.42 \pm 38.36^{\text {bcd }}$ & $7.40 \pm 0.06^{\mathrm{h}}$ & $2.46 \pm 0.01^{\mathrm{ef}}$ & $23.40 \pm 0.08^{\mathrm{d}}$ & $3.86 \pm 0.04^{\mathrm{c}}$ & $-0.06 \pm 0.04^{\text {cd }}$ & $73.98 \pm 0.07^{\mathrm{bc}}$ & $6.88 \pm 0.05^{\text {cd }}$ & $1.02 \pm 0.01^{\text {abc }}$ \\
\hline 2016 & $0.93 \pm 0.06^{\mathrm{c}}$ & $7.98 \pm 0.07^{\mathrm{c}}$ & $73.91 \pm 0.42^{\mathrm{e}}$ & $13.10 \pm 0.10^{\mathrm{c}}$ & $3.18 \pm 0.02^{\mathrm{g}}$ & $306.12 \pm 32.26^{\mathrm{cd}}$ & $8.50 \pm 0.00^{\circ}$ & $3.35 \pm 0.27^{\mathrm{c}}$ & $22.70 \pm 0.14^{\mathrm{e}}$ & $2.50 \pm 0.06^{\mathrm{h}}$ & $-0.51 \pm 0.05^{\mathrm{e}}$ & $74.69 \pm 0.14^{\mathrm{a}}$ & $9.88 \pm 0.48^{\mathrm{a}}$ & $0.91 \pm 0.10^{\mathrm{bc}}$ \\
\hline 2017 & $1.36 \pm 0.08^{\mathrm{a}}$ & $7.89 \pm 0.07^{\mathrm{c}}$ & $78.69 \pm 0.45^{\mathrm{a}}$ & $14.00 \pm 0.01^{\mathrm{b}}$ & $3.45 \pm 0.03^{\mathrm{c}}$ & $367.63 \pm 33.90^{\text {bc }}$ & $9.10 \pm 0.06^{\mathrm{a}}$ & $4.43 \pm 0.08^{\mathrm{a}}$ & $23.24 \pm 0.10^{\mathrm{d}}$ & $3.05 \pm 0.03^{\mathrm{f}}$ & $-0.84 \pm 0.09^{f}$ & $74.11 \pm 0.10^{\mathrm{bc}}$ & $9.38 \pm 0.00^{\mathrm{a}}$ & $1.00 \pm 0.00^{\mathrm{abc}}$ \\
\hline
\end{tabular}


Table 2: Individual organic acid content of Cabernet Sauvignon wines of ten successive vintages

\begin{tabular}{|c|c|c|c|c|c|c|c|c|c|}
\hline Vintage & $\begin{array}{l}\text { Oxalic acid } \\
\left(\mathrm{g} \mathrm{L}^{-1}\right)\end{array}$ & $\begin{array}{l}\text { Tartaric acid } \\
\left(\mathrm{g} \mathrm{L}^{-1}\right)\end{array}$ & $\begin{array}{l}\text { Pyruvic acid } \\
\left(\mathrm{g} \mathrm{L}^{-1}\right)\end{array}$ & $\begin{array}{l}\text { Malic acid } \\
\left(\mathrm{g} \mathrm{L}^{-1}\right)\end{array}$ & $\begin{array}{l}\text { Lactic acid } \\
\left(\mathrm{g} \mathrm{L}^{-1}\right)\end{array}$ & $\begin{array}{l}\text { Acetic acid } \\
\left(\mathrm{g} \mathrm{L}^{-1}\right)\end{array}$ & $\begin{array}{l}\text { Citric acid } \\
\left(\mathrm{g} \mathrm{L}^{-1}\right)\end{array}$ & $\begin{array}{l}\text { Succinic } \\
\text { acid }\left(\mathrm{g} \mathrm{L}^{-1}\right)\end{array}$ & $\begin{array}{l}\text { Total organic } \\
\text { acid }\left(\mathrm{g} \mathrm{L}^{-1}\right)\end{array}$ \\
\hline 2008 & $0.27 \pm 0.02^{\mathrm{g}}$ & $2.32 \pm 0.02^{\mathrm{i}}$ & $0.06 \pm 0.00^{\mathrm{f}}$ & $1.96 \pm 0.01^{\mathrm{b}}$ & $2.53 \pm 0.02^{\mathrm{g}}$ & $0.75 \pm 0.01^{\mathrm{f}}$ & n.d. & $0.36 \pm 0.01^{b}$ & $8.25 \pm 0.68^{\mathrm{d}}$ \\
\hline 2009 & $0.35 \pm 0.02^{\mathrm{e}}$ & $1.69 \pm 0.01^{\mathrm{j}}$ & $0.10 \pm 0.01^{\text {ef }}$ & $1.38 \pm 0.01^{\mathrm{f}}$ & $2.82 \pm 0.01^{\mathrm{e}}$ & $0.84 \pm 0.01^{\mathrm{e}}$ & n.d. & $0.35 \pm 0.01^{\mathrm{b}}$ & $7.53 \pm 0.45^{\mathrm{e}}$ \\
\hline 2011 & $0.38 \pm 0.01^{\mathrm{d}}$ & $2.98 \pm 0.02^{\mathrm{d}}$ & $0.13 \pm 0.02^{\mathrm{de}}$ & $1.95 \pm 0.01^{\mathrm{b}}$ & $4.55 \pm 0.05^{\mathrm{a}}$ & $0.35 \pm 0.01^{\mathrm{i}}$ & n.d. & $0.26 \pm 0.01^{\mathrm{e}}$ & $10.60 \pm 0.84^{b}$ \\
\hline 2012 & $0.31 \pm 0.02^{f}$ & $2.50 \pm 0.03^{f}$ & $0.09 \pm 0.00^{\mathrm{ef}}$ & $1.53 \pm 0.01^{\mathrm{e}}$ & $2.84 \pm 0.02^{\mathrm{d}}$ & $0.97 \pm 0.01^{\mathrm{c}}$ & n.d. & $0.20 \pm 0.01^{\mathrm{f}}$ & $8.44 \pm 0.52^{\mathrm{d}}$ \\
\hline 2013 & $0.52 \pm 0.03^{\mathrm{a}}$ & $2.37 \pm 0.02^{\mathrm{h}}$ & $0.80 \pm 0.01^{\mathrm{a}}$ & $1.77 \pm 0.01^{\mathrm{c}}$ & $2.70 \pm 0.02^{\mathrm{f}}$ & $0.6 \pm 0.01^{\mathrm{g}}$ & n.d. & $0.28 \pm 0.01^{\mathrm{d}}$ & $9.04 \pm 0.76^{\mathrm{e}}$ \\
\hline 2014 & $0.37 \pm 0.02^{\mathrm{d}}$ & $2.45 \pm 0.02^{\mathrm{g}}$ & $0.12 \pm 0.01^{\mathrm{def}}$ & $1.39 \pm 0.01^{\mathrm{f}}$ & $1.37 \pm 0.01^{\mathrm{i}}$ & $0.75 \pm 0.01^{\mathrm{f}}$ & n.d. & $0.02 \pm 0.01^{\mathrm{g}}$ & $6.47 \pm 0.43^{\mathrm{f}}$ \\
\hline 2015 & $0.40 \pm 0.02^{\mathrm{d}}$ & $4.31 \pm 0.03^{\mathrm{a}}$ & $0.17 \pm 0.01^{\mathrm{c}}$ & $1.69 \pm 0.01^{\mathrm{d}}$ & $2.96 \pm 0.02^{\mathrm{c}}$ & $0.91 \pm 0.01^{\mathrm{d}}$ & n.d. & $0.32 \pm 0.01^{\mathrm{c}}$ & $10.75 \pm 0.89^{b}$ \\
\hline 2016 & $0.49 \pm 0.02^{b}$ & $3.44 \pm 0.02^{\mathrm{b}}$ & $0.72 \pm 0.01^{b}$ & $2.39 \pm 0.02^{\mathrm{a}}$ & $3.57 \pm 0.02^{\mathrm{b}}$ & $1.08 \pm 0.01^{\mathrm{a}}$ & n.d. & $0.31 \pm 0.01^{\mathrm{c}}$ & $12.01 \pm 0.93^{\mathrm{a}}$ \\
\hline 2017 & $0.43 \pm 0.03^{c}$ & $3.33 \pm 0.02^{\mathrm{c}}$ & $0.06 \pm 0.01^{\mathrm{f}}$ & $0.98 \pm 0.01^{\mathrm{g}}$ & $0.56 \pm 0.01^{\mathrm{j}}$ & $0.37 \pm 0.01^{\mathrm{h}}$ & n.d. & $0.25 \pm 0.01^{\mathrm{e}}$ & $5.95 \pm 0.24^{\mathrm{g}}$ \\
\hline
\end{tabular}

The result expressed as mean value and standard deviations over three replications.

$\mathrm{a}, \mathrm{b}, \mathrm{c}, \mathrm{d}, \mathrm{e}, \mathrm{f}, \mathrm{g}, \mathrm{h}, \mathrm{i}, \mathrm{j}$ Different letters in the same row indicate statistical differences at the 0.05 level according to Duncan test.

n.d., not detect.
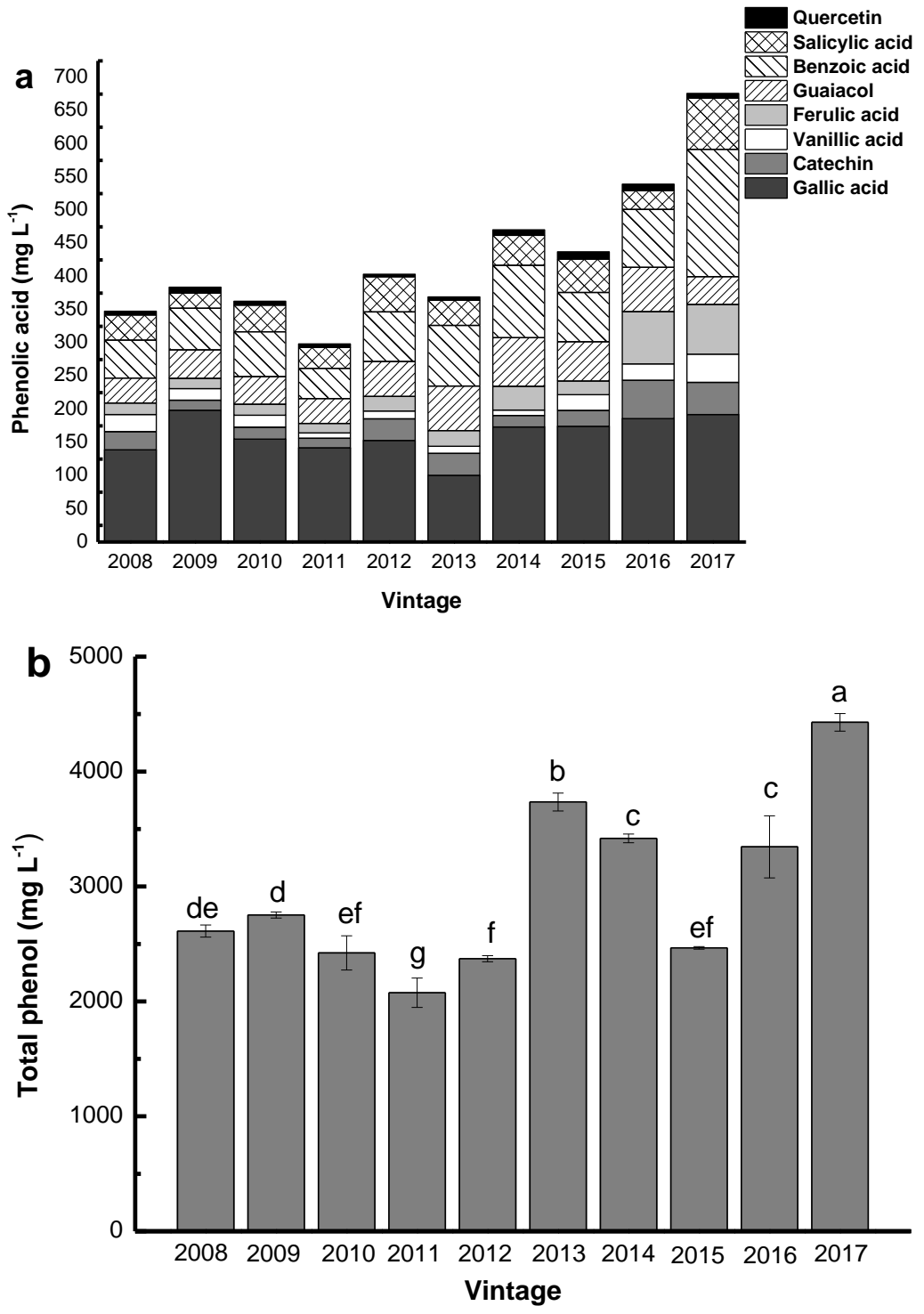

Fig. 1: (a) Individual phenolics and (b) total phenol content of Cabernet Sauvignon wines of ten successive vintages ((2008-2017). The mean and standard deviation of three independent experiments are shown in (b). Different lettters in the different samples indicate significant difference at the 0.05 level according to Duncan test 


\section{Phenolics of Wines}

Figure 1 summarized the individual phenolics in wine samples. The total phenol content of wines varied from 2370 to $4430 \mathrm{mg} \mathrm{L}^{-1}$, which was higher than the change of $1402 \sim 3130 \mathrm{mg} \mathrm{L}^{-1}$ in Cabernet Sauvignon wines observed in the previous report (Li et al., 2009). This may be due to the geographical superiority of this region. Vintage showed statistically significant effect on individual phenolics such as gallic acid, benzoic acid, ferulic acid, salicylic acid and vanillic acid. Gallic acid accounted for the highest value among phenolic acid ranging from 100.48 to $198.66 \mathrm{mg} \mathrm{L}^{-1}$, followed by benzoic acid (45.73 to $191.96 \mathrm{mg} \mathrm{L}^{-1}$ ). Gallic acid was reported to account for nearly $50 \%$ of the total phenolic acid content (Van Leeuw et al., 2014). High content of gallic acid come from the hydrolysis of flavonoid gallate derived from grape skin (Peri et al., 2015). The vintage of 2017 showed significantly higher content of phenolics due to higher content of benzoic, salicylic and vanillic acid. This result may support the suggestion that salicylic and vanillic acid could be 'marker compounds' for the differentiation of young wines (Perestrelo et al., 2020). It is worth noting that the ferulic acid content was three times higher in vintages from 2016 and 2017 compared to the vintages from 2008, 2009, 2010 and 2012. Catechins, a group of flavan-3-ols, accounted for a small proportion of phenolics with the exception of 2016 and 2017. According to literatures, red wines from different harvests contain, on average, $62.82 \mathrm{mg} \mathrm{L}^{-1}$ of catechin (Fanzone et al., 2012; Van Leeuw et al., 2014). The concentration of catechin in Cabernet Sauvignon wines ranged from 14.19 to $57.69 \mathrm{mg} \mathrm{L}^{-1}$. From healthy point of view, flavan-3-ols play an important role in maintaining neurological health (Forester and Waterhouse, 2009). Quercetin, a group of flavonols, was detected in trace amounts compared with other compounds and no significant differences $(p>0.05)$ were observed for the content of quercetin between different samples.

\section{Volatile Compounds of Wines}

Fifty volatile compounds consisting of 24 esters, 9 benzene compounds, 4 alcohols, 3 acids, 5 C6 compounds, 5 terpenes and C13-norisoprenoid were identified and quantified in wine samples (Table 3 ).

Table 3: Concentration of the volatile compounds in Cabernet Sauvignon wines of ten successive vintages

\begin{tabular}{|c|c|c|c|c|c|c|c|c|c|c|}
\hline & \\
\hline & $2008\left(\mu \mathrm{g} \mathrm{L}^{-1}\right)$ & $2009\left(\mu \mathrm{g} \mathrm{L}^{-1}\right)$ & $2010\left(\mu \mathrm{g} \mathrm{L}^{-1}\right)$ & $2011\left(\mu \mathrm{g} \mathrm{L}^{-1}\right)$ & $2012\left(\mu \mathrm{g} \mathrm{L}^{-1}\right)$ & $2013\left(\mu \mathrm{g} \mathrm{L}^{-1}\right)$ & $2014\left(\mu \mathrm{g} \mathrm{L}^{-1}\right)$ & $2015\left(\mu \mathrm{g} \mathrm{L}^{-1}\right)$ & $2016\left(\mu \mathrm{g} \mathrm{L}^{-1}\right)$ & $2017\left(\mu \mathrm{g} \mathrm{L}^{-1}\right)$ \\
\hline C6 compounds & $43.98 \pm 5.30^{\mathrm{j}}$ & $136.86 \pm 10.18^{\mathrm{h}}$ & $176.06 \pm 11.02^{f}$ & $171.24 \pm 3.95^{m}$ & $188.05 \pm 11.54^{\mathrm{e}}$ & $207.56 \pm 15.50^{d}$ & $216.53 \pm 16.75^{\mathrm{c}}$ & $221.02 \pm 18.94^{b}$ & $243.94 \pm 11.68^{\mathrm{a}}$ & $105.19 \pm 9.64^{i}$ \\
\hline 1-hexanol & $17.18 \pm 1.19^{j}$ & $111.80 \pm 5.78^{\mathrm{h}}$ & $153.42 \pm 1.12^{\mathrm{f}}$ & $145.38 \pm 2.50^{\mathrm{g}}$ & $165.58 \pm 10.36^{\mathrm{c}}$ & $183.17 \pm 5.25^{\mathrm{d}}$ & $195.34 \pm 12.36^{\circ}$ & $200.64 \pm 18.64^{\mathrm{b}}$ & $210.35 \pm 6.35^{\mathrm{a}}$ & $84.65 \pm 1.87^{i}$ \\
\hline (E)-3-hexen-1-ol & $9.58 \pm 0.05^{\mathrm{a}}$ & $8.56 \pm 1.00^{\mathrm{ab}}$ & $7.24 \pm 1.01^{\text {bcd }}$ & $7.98 \pm 0.96^{\mathrm{bc}}$ & $6.75 \pm 0.49^{\mathrm{dede}}$ & $6.13 \pm 0.03^{\text {def }}$ & $4.71 \pm 0.10^{f}$ & $5.61 \pm 0.48^{\text {def }}$ & $5.87 \pm 1.07^{\mathrm{dec}}$ & $5.26 \pm 1.78^{\text {ef }}$ \\
\hline (Z)-3-hexen-1-ol & $10.64 \pm 1.50^{\mathrm{a}}$ & $9.25 \pm 0.87^{\text {ab }}$ & $7.58 \pm 0.87^{\mathrm{bc}}$ & $9.53 \pm 0.11^{\mathrm{ab}}$ & $7.03 \pm 0.40^{\mathrm{od}}$ & $7.51 \pm 0.09^{\mathrm{dd}}$ & $6.83 \pm 0.73^{\mathrm{d}}$ & $6.25 \pm 0.970^{\mathrm{d}}$ & $6.54 \pm 1.14^{\mathrm{d}}$ & $5.68 \pm 0.84^{\mathrm{d}}$ \\
\hline 5-methyl-2-furancarboxaldehyde & n.d & n.d & n.d & n.d & n.d & n.d & n.d & n.d & $13.54 \pm 1.35$ & \\
\hline Terpene and C13-norisoprenoids & $69.08 \pm 4.78^{i}$ & $79.82 \pm 5.12^{\mathrm{b}}$ & $78.82 \pm 5.04^{c}$ & $71.97 \pm 4.85^{\mathrm{f}}$ & $66.69 \pm 4.58^{i}$ & $74.77 \pm 4.95^{\mathrm{d}}$ & $70.18 \pm 4.77^{x}$ & $70.02 \pm 4.68^{\mathrm{h}}$ & $73.64 \pm 4.82^{\mathrm{e}}$ & $131.87 \pm 10.87^{\mathrm{a}}$ \\
\hline 4-terpineol & $22.48 \pm 1.57^{\mathrm{cd}}$ & $22.65 \pm 0.90^{\text {cd }}$ & $25.67 \pm 1.18^{\text {ab }}$ & $26.84 \pm 1.03^{\mathrm{a}}$ & $21.57 \pm 0.94^{\mathrm{de}}$ & $24.52 \pm 1.58^{\mathrm{bc}}$ & $26.84 \pm 1.19^{\mathrm{a}}$ & $22.54 \pm 0.94^{\text {dd }}$ & $20.35 \pm 0.84^{\text {de }}$ & $19.65 \pm 0.93^{\mathrm{e}}$ \\
\hline L- alpha. -terpineol & $24.85 \pm 3.52^{\mathrm{a}}$ & $23.65 \pm 1.07^{\mathrm{a}}$ & $22.51 \pm 1.11^{\mathrm{ab}}$ & $20.34 \pm 1.02^{\mathrm{b}}$ & $21.35 \pm 0.73^{\text {ab }}$ & $22.35 \pm 1.20^{\text {sb }}$ & $20.83 \pm 1.19^{\text {ab }}$ & $21.36 \pm 1.03^{\text {ab }}$ & $22.54 \pm 1.10^{\text {ab }}$ & $19.52 \pm 1.02^{\mathrm{b}}$ \\
\hline Terpinen-4-ol & $13.23 \pm 3.83^{\mathrm{a}}$ & $25.96 \pm 4.07^{\mathrm{a}}$ & $24.06 \pm 1.41^{\mathrm{a}}$ & $17.74 \pm 1.44^{\mathrm{a}}$ & $17.49 \pm 0.73^{\mathrm{a}}$ & $21.41 \pm 0.84^{\mathrm{a}}$ & $14.97 \pm 0.95^{\mathrm{a}}$ & $19.54 \pm 1.36^{a}$ & $24.47 \pm 3.13^{\mathrm{a}}$ & $87.12 \pm 125.39^{\mathrm{a}}$ \\
\hline$\beta$-damascenone & $8.52 \pm 1.72^{\mathrm{a}}$ & $7.56 \pm 0.28^{\mathrm{ab}}$ & $6.58 \pm 0.25^{\mathrm{bc}}$ & $7.05 \pm 0.70^{\mathrm{b}}$ & $6.28 \pm 0.89^{\mathrm{bc}}$ & $6.49 \pm 0.12^{\mathrm{bc}}$ & $7.54 \pm 0.29^{\mathrm{ab}}$ & $6.58 \pm 0.43^{\mathrm{bc}}$ & $6.28 \pm 0.11^{\mathrm{bc}}$ & $5.58 \pm 0.11^{\circ}$ \\
\hline Benzene compounds & $1115.73 \pm 326.93^{\mathrm{i}}$ & $2069.47 \pm 1192.64^{\mathrm{a}}$ & $1669.72 \pm 214.65^{\mathrm{c}}$ & $1411.95 \pm 194.61^{\mathrm{f}}$ & $1257.13 \pm 100.35^{\mathrm{x}}$ & $1231.50 \pm 183.64^{\mathrm{h}}$ & $1115.16 \pm 86.34^{\mathrm{j}}$ & $1440.28 \pm 88.30^{\mathrm{d}}$ & $1421.43 \pm 96.35^{\mathrm{e}}$ & $1819.11 \pm 100.84^{b}$ \\
\hline $\begin{array}{l}\text { Benzyl alcohol } \\
\text { Dals }\end{array}$ & $30.42 \pm 9.14^{\mathrm{d}}$ & $54.18 \pm 28.58^{\mathrm{c}}$ & $35.93 \pm 5.81^{d \mathrm{~d}}$ & $91.38 \pm 8.39^{\mathrm{b}}$ & $40.20 \pm 5.40^{\mathrm{dd}}$ & $31.30 \pm 5.40^{d}$ & $30.93 \pm 3.82^{\mathrm{d}}$ & & $22.07 \pm 2.39^{d}$ & $37.41 \pm 3.27^{\mathrm{cd}}$ \\
\hline Phenethyl alcohol & $1060.57 \pm 325.91^{\mathrm{a}}$ & $1941.08 \pm 1191.73^{\mathrm{a}}$ & $1569.96 \pm 204.40^{\mathrm{a}}$ & $1235.11 \pm 158.42^{\mathrm{a}}$ & $1166.25 \pm 95.17^{\mathrm{a}}$ & $1158.41 \pm 169.49^{\mathrm{a}}$ & $1022.07 \pm 66.40^{\mathrm{a}}$ & $1232.91 \pm 15.15^{\mathrm{a}}$ & $1350.70 \pm 95.73^{a}$ & $1721.93 \pm 1005.11^{\mathrm{a}}$ \\
\hline Phenol & $2.02 \pm 0.78^{\mathrm{bc}}$ & $6.78 \pm 2.02^{\mathrm{a}}$ & $6.28 \pm 0.50^{\mathrm{a}}$ & $4.37 \pm 1.00^{\text {the }}$ & $3.92 \pm 0.96^{\mathrm{bc}}$ & $4.35 \pm 0.35^{\text {bic }}$ & $4.96 \pm 2.56^{\text {ab }}$ & $4.19 \pm 0.86^{\text {ab }}$ & $3.13 \pm 1.42^{\mathrm{bc}}$ & $1.90 \pm 0.58^{\circ}$ \\
\hline 2,4-di-tert-butylphenol & $11.47 \pm 1.03^{\mathrm{a}}$ & $21.81 \pm 18.15^{\mathrm{a}}$ & $20.11 \pm 4.34^{a}$ & $16.31 \pm 2.39^{\mathrm{a}}$ & $14.40 \pm 3.38^{\mathrm{a}}$ & $11.65 \pm 0.23^{\mathrm{a}}$ & $15.62 \pm 6.25^{\mathrm{a}}$ & $17.96 \pm 3.04^{\mathrm{a}}$ & $14.86 \pm 2.56^{\mathrm{a}}$ & $25.53 \pm 16.84^{\mathrm{a}}$ \\
\hline $\begin{array}{l}\text { phenylethylene } \\
\text { ple }\end{array}$ & $9.18 \pm 0.08^{c}$ & $22.52 \pm 8.44^{\mathrm{a}}$ & $17.02 \pm 1.06^{\text {alc }}$ & $16.50 \pm 4.95^{\text {acc }}$ & $13.66 \pm 2.01^{\mathrm{bc}}$ & $\begin{array}{l}1.00 \pm .25 \\
\text { n.d. }\end{array}$ & $19.20 \pm 4.57^{\text {ab }}$ & $18.14 \pm 5.28^{\mathrm{ab}}$ & $18.20 \pm 1.86^{\text {ab }}$ & $26.14 \pm 7.59^{\mathrm{a}}$ \\
\hline 2-methylnaphthalene & $\begin{array}{l}\text { 9.18 } \\
\text { n.d. }\end{array}$ & $9.42 \pm 3.76^{\text {ab }}$ & $\begin{array}{l}17.42 \pm 1.00 \\
9.41 \pm 1.48^{\mathrm{ab}}\end{array}$ & $\begin{array}{l}10.50 \pm 4.9 \mathrm{~S} \\
10.77 \pm 0.88^{\mathrm{a}}\end{array}$ & $\begin{array}{l}15.00 \pm 2.01 \\
\text { n.d. }\end{array}$ & $\begin{array}{l}\text { n.o. } \\
7.41 \pm 1.60^{\text {ab }}\end{array}$ & $\begin{array}{l}19.2 \pm \pm 4.57 \\
6.09 \pm 1.02^{\mathrm{b}}\end{array}$ & $\begin{array}{l}18.14 \pm 3.28 \\
\text { n.d. }\end{array}$ & $\begin{array}{l}18.20 \pm 1.80 \\
\text { n.d. }\end{array}$ & $\begin{array}{l}20.14 \pm . .59^{\prime} \\
\text { n.d. }\end{array}$ \\
\hline 1 -methylnaphthalene & $\begin{array}{l}\text { n.d. } \\
\text { n.d. }\end{array}$ & $13.68 \pm 1.14^{\mathrm{a}}$ & $11.01 \pm 1.02^{\mathrm{a}}$ & n.d. & $8.52 \pm 3.81^{\mathrm{b}}$ & $6.79 \pm 0.13^{\mathrm{b}}$ & $3.97 \pm 0.41^{\mathrm{c}}$ & n.d. & n.d. & \\
\hline Benzaldehyde & n.d. & n.d. & n.d. & $36.19 \pm 1.22^{\mathrm{a}}$ & $10.18 \pm 0.88^{\mathrm{b}}$ & $11.59 \pm 1.84^{\mathrm{b}}$ & $10.97 \pm 2.17^{\mathrm{b}}$ & $12.62 \pm 1.96^{b}$ & $7.96 \pm 0.97^{\circ}$ & $6.20 \pm 0.23^{\mathrm{c}}$ \\
\hline Eugenol & $2.07 \pm 0.07^{\mathrm{b}}$ & n.d & n.d & $1.32 \pm 0.22^{\mathrm{c}}$ & n.d & n.d & $1.35 \pm 0.27^{\circ}$ & n.d & $4.51 \pm 0.20^{\mathrm{a}}$ & n.d \\
\hline Acid & $151.44 \pm 20.05^{\mathrm{bc}}$ & $76.7 \pm 18.65^{\mathrm{e}}$ & $237.86^{\mathrm{a}} \pm 35.68$ & $258.48 \pm 28.34^{\mathrm{a}}$ & $183.13 \pm 22.08^{b}$ & $75.66 \pm 17.34^{e}$ & $148.68 \pm 19.86^{\text {cde }}$ & $179.17 \pm 21.30^{\mathrm{b}}$ & $125.84 \pm 18.64^{\text {cd }}$ & $129.12 \pm 18.85^{\text {de }}$ \\
\hline Hexanoic acid & $48.79 \pm 10.94^{\mathrm{bc}}$ & $\begin{array}{l}\text { T. } \\
24.18 \pm 10.00^{c}\end{array}$ & $59.08 \pm 4.50^{\text {ab }}$ & 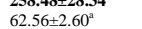 & $\begin{array}{l}18.1 .15 \pm 22.08 \mathrm{~s} \\
52.51 \pm 8.91^{\text {tace }}\end{array}$ & $30.30 \pm 2.23^{\mathrm{de}}$ & $\begin{array}{l}118.68 \pm 19.8 .86 \\
52.47 \pm 9.07^{\text {the }}\end{array}$ & $39.88 \pm 6.63^{\mathrm{cd}^{\mathrm{d}}}$ & $40.24 \pm 4.85^{\text {cd }}$ & $18.26 \pm 1.10^{\circ}$ \\
\hline Octanoic acid & $97.65 \pm 7.80^{\circ}$ & $38.28 \pm 23.14^{d}$ & $161.15 \pm 28.16^{\text {ab }}$ & $168.90 \pm 22.87^{\mathrm{a}}$ & $116.22 \pm 35.90^{\mathrm{c}}$ & $39.44 \pm 10.70^{\mathrm{d}}$ & $83.93 \pm 26.39^{\text {cd }}$ & $121.31 \pm 33.67^{\text {be }}$ & $76.51 \pm 11.20^{\text {ad }}$ & $82.02 \pm 30.00^{\mathrm{cd}}$ \\
\hline 1-nonanol & $25.25 \pm 1.00^{\text {be }}$ & $28.13 \pm 3.56^{\mathrm{bc}}$ & $26.47 \pm 34.90^{\mathrm{ac}}$ & $30.43 \pm 1.80^{\mathrm{bc}}$ & $22.14 \pm 1.22^{\circ}$ & $30.30 \pm 2.59^{\mathrm{bc}}$ & $26.21 \pm 2.27^{\mathrm{bc}}$ & $54.33 \pm 4.05^{\mathrm{a}}$ & $26.59 \pm 2.90^{\mathrm{bc}}$ & $21.31 \pm 2.87^{\circ}$ \\
\hline $\begin{array}{l}\text { n-hroptanol } \\
\text { nehel }\end{array}$ & $12.39 \pm 1.03^{\mathrm{b}}$ & $12.52 \pm 4.75^{\mathrm{b}}$ & $\begin{array}{l}20.47 \pm 34.90 \mathrm{~d} \\
12.94 \pm 0.75^{\mathrm{b}}\end{array}$ & $\begin{array}{l}30.4 \pm \pm 1.00 \\
\text { n.d. }\end{array}$ & $\begin{array}{l}2.14 \pm 1.22 \\
\text { n.d. }\end{array}$ & $19.45 \pm 1.17^{\mathrm{b}}$ & $10.01 \pm 0.80^{\mathrm{b}}$ & $18.88 \pm 0.31^{\mathrm{b}}$ & $19.58 \pm 1.27^{\mathrm{b}}$ & $104.20 \pm 95.13^{\mathrm{a}}$ \\
\hline 3-methylthiopropanol & $5.47 \pm 1.72^{d}$ & $6.78 \pm 5.90^{\mathrm{ab}}$ & $13.48 \pm 3.67^{\text {th }}$ & $14.57 \pm 2.85^{\mathrm{a}}$ & $11.04 \pm 1.04^{\text {abc }}$ & $9.12 \pm 0.79^{\mathrm{bcd}}$ & & $9.63 \pm 1.17^{\text {bcd }}$ & $8.04 \pm 1.50^{\mathrm{cd}}$ & $7.70=$ \\
\hline 1-pentanol & $1075.46 \pm 1.13^{\mathrm{c}}$ & $\begin{array}{l}\text { n.d. } \\
\text { n.t.9. }\end{array}$ & $1996.67 \pm 113.95^{\mathrm{b}}$ & $\begin{array}{l}\text { n.d. } \\
\text { n.d.0J }\end{array}$ & $2656.47 \pm 11.18^{\mathrm{a}}$ & $\begin{array}{l}\text { n.d. } \\
\text { n. }\end{array}$ & $2460.83 \pm 8.49^{\mathrm{a}}$ & $2185.67 \pm 296.98^{\mathrm{b}}$ & $\begin{array}{l}0.0+ \pm 1.00 \\
\text { n.d. }\end{array}$ & \\
\hline Esters & $5324.6 \pm 276.51^{d}$ & $5654.88 \pm 289.34^{\mathrm{b}}$ & $6279.59 \pm 302.37^{\mathrm{a}}$ & $6138.49 \pm 300.69^{\mathrm{a}}$ & $4912.62 \pm 277.60^{\text {ef }}$ & $5453.93 \pm 280.69^{c}$ & $4955.3 \pm 279.64^{\mathrm{e}}$ & $4132.32 \pm 250.31^{\mathrm{g}}$ & $3997.77 \pm 245.36^{\mathrm{h}}$ & $4827.32 \pm 264.87^{f}$ \\
\hline Ethyl butyrate & $22.53 \pm 22.68^{\text {ab }}$ & $15.90 \pm 1.81^{1 \mathrm{~b}}$ & $30.02 \pm 3.72^{\mathrm{a}}$ & $19.25 \pm 2.08^{\text {th }}$ & $30.35 \pm 3.44^{\mathrm{a}}$ & $23.10 \pm 16.84^{\text {b }}$ & $1.52 \pm 0.84^{\circ}$ & $10.86 \pm 12.00^{\mathrm{bc}}$ & $0.56 \pm 0.25^{\circ}$ & $19.83 \pm 3.84^{\text {th }}$ \\
\hline Ethyl 2-methylbutyrate & $20.94 \pm 5.56^{\mathrm{b}}$ & $20.96 \pm 10.51^{\mathrm{b}}$ & $39.94 \pm 1.02^{\mathrm{a}}$ & $4.42 \pm 0.85^{\circ}$ & $\begin{array}{l}3.30 \pm .44 \\
\text { n.d. }\end{array}$ & $21.35 \pm 0.87^{\mathrm{b}}$ & $\begin{array}{l}1 . .2 \pm 0.04 \\
\text { n.d. }\end{array}$ & $\begin{array}{l}10.00 \pm 12.00 \\
\text { n.d. }\end{array}$ & $\begin{array}{l}\text { n.d. } \\
\text { n. }\end{array}$ & $\begin{array}{l}1.03 \pm .04 \\
\text { n.d. }\end{array}$ \\
\hline Ethyl isovalerate & $24.17 \pm 7.71^{\text {ab }}$ & $30.08 \pm 8.88^{\mathrm{a}}$ & $41.49 \pm 17.99^{\mathrm{a}}$ & $10.91 \pm 0.99^{b}$ & n.d. & $40.84 \pm 1.16^{\mathrm{a}}$ & n.d. & n.d. & $12.55 \pm 2.06^{\mathrm{b}}$ & n.d. \\
\hline Isoamyl acetate & $69.21 \pm 18.12^{\mathrm{bc}}$ & $71.50 \pm 7.49^{\mathrm{bc}}$ & $59.17 \pm 3.32^{\mathrm{dd}}$ & $41.19 \pm 0.72^{\circ}$ & $58.68 \pm 1.56^{\text {dd }}$ & $68.66 \pm 7.04^{\mathrm{bc}}$ & $59.77 \pm 1.06^{\mathrm{cd}}$ & $81.01 \pm 6.93^{\text {ab }}$ & $86.27 \pm 6.75^{\mathrm{a}}$ & $54.11 \pm 2.72^{\mathrm{d}}$ \\
\hline Ethyl hexanoate & $971.65 \pm 60.45^{\text {ab }}$ & $685.10 \pm 93.19^{d}$ & $1046.01 \pm 124.30^{\mathrm{a}}$ & $925.06 \pm 57.00^{\mathrm{bc}}$ & $860.59 \pm 1.06^{\circ}$ & $852.94 \pm 1.08^{\mathrm{c}}$ & $747.99 \pm 1.19^{\mathrm{d}}$ & $485.20 \pm 27.21^{\mathrm{c}}$ & $\begin{array}{l}\infty .27 \pm 0 . / 3 \\
\text { n.d. }\end{array}$ & $450.99 \pm 1.18^{\mathrm{e}}$ \\
\hline 2-hexenoic acid, ethyl ester & $11.27 \pm 2.43^{\mathrm{bc}}$ & $12.30 \pm 6.30^{\mathrm{bc}}$ & $14.88 \pm 1.97^{\mathrm{b}}$ & $13.63 \pm$ & $12.39 \pm 1.23^{\mathrm{bc}}$ & $16.28 \pm 0.87^{\mathrm{b}}$ & $32.81 \pm 4.46^{a}$ & $15.11 \pm 1.97^{\mathrm{b}}$ & $12.71 \pm 0.92^{\mathrm{b}}$ & $59.30 \pm 0.09^{\circ}$ \\
\hline Methyl octanoate & $24.14 \pm 8.53^{\mathrm{a}}$ & $14.94 \pm 0.93^{\mathrm{b}}$ & $19.18 \pm 2.12^{\mathrm{ab}}$ & $24.67 \pm 2.05^{\mathrm{a}}$ & $14.92 \pm 2.34^{\mathrm{b}}$ & $19.85 \pm 0.54^{\text {b }}$ & $16.34 \pm 2.73^{\mathrm{b}}$ & $15.09 \pm 3.83^{\mathrm{b}}$ & $16.37 \pm 1.72^{\mathrm{b}}$ & $13.68 \pm 0.71^{\mathrm{b}}$ \\
\hline Ethyl octanoate & $2007.53 \pm 980.70^{\mathrm{a}}$ & $\begin{array}{l}14.94 \pm \pm 0.95 \\
1899.34 \pm 974.17^{\mathrm{a}}\end{array}$ & $\begin{array}{l}2197.70 \pm 266.16^{a} \\
2197\end{array}$ & $\begin{array}{l}24.007 \pm 2.05 \\
2490.790 .25^{\mathrm{a}}\end{array}$ & $\begin{array}{l}14.92 \pm 2.34 \\
1774.78 \pm 221.67^{\mathrm{a}}\end{array}$ & $\begin{array}{l}19.895 .88 \pm 96.24^{\mathrm{a}} \\
1995\end{array}$ & $\begin{array}{l}10.3 \pm \pm 2.35 \\
2082.36 \pm 59.14^{\mathrm{a}}\end{array}$ & $1835.88 \pm 399.24^{\mathrm{a}}$ & $\begin{array}{l}10.3 / \pm 1 . / 2 \\
1742.23 \pm 242.34^{\mathrm{a}}\end{array}$ & $1594.05 \pm 152.78^{\mathrm{a}}$ \\
\hline Isopentyl hexanoate & $21.20 \pm 6.54^{\mathrm{d}}$ & $17.67 \pm 0.98^{d \mathrm{di}}$ & $43.59 \pm 1.40^{\mathrm{b}}$ & $11.47 \pm 5.96^{\mathrm{d}}$ & $21.74 \pm 6.09^{\mathrm{di}}$ & $18.94 \pm 3.48^{\text {ad }}$ & $23.00 \pm 10.94^{\circ}$ & n.d. & $14.85 \pm 1.40^{\mathrm{di}}$ & $93.34 \pm 2.15^{\mathrm{a}}$ \\
\hline Ethyl nonanoate & $54.50 \pm 19.47^{\mathrm{a}}$ & $90.74 \pm 5.36^{\mathrm{a}}$ & n.d. & n.d. & & $\begin{array}{l}10 .+1.5 .40 \\
\text { n.d. }\end{array}$ & $30.47 \pm 13.89^{\mathrm{b}}$ & $72.29 \pm 2.51^{\mathrm{a}}$ & $\begin{array}{l}11.05 \pm 1.40 \\
\text { n.d. }\end{array}$ & $29.60 \pm 0.92^{\mathrm{b}}$ \\
\hline Bornyl acetate & $14.48 \pm 0.83^{\circ}$ & $18.86 \pm 0.49^{\circ}$ & n.d. & $18.20 \pm 0.15^{\mathrm{c}}$ & $15.35 \pm 0.42^{\mathrm{c}}$ & n.d. & n.d. & $29.95 \pm 9.83^{\mathrm{b}}$ & n.d. & $209.92 \pm 1.17^{\mathrm{a}}$ \\
\hline Methyl n-caprate & $14.94 \pm 1.05^{\text {sbc }}$ & $10.96 \pm 1.69^{c}$ & $14.33 \pm 1.67^{\text {the }}$ & $18.34 \pm 1.10^{\mathrm{a}}$ & $14.59 \pm 5.52^{\text {abc }}$ & $14.03 \pm 2.53^{3 \mathrm{bc}}$ & $12.71 \pm 0.27^{\mathrm{bc}}$ & $15.96 \pm 2.74^{\text {ab }}$ & $10.49 \pm 2.69^{c}$ & $12.53 \pm 0.95^{\mathrm{bc}}$ \\
\hline $\begin{array}{l}\text { Ethyl caprate } \\
\text { Elte }\end{array}$ & $305.48 \pm 161.70^{\circ}$ & $400.02 \pm 25.02^{\mathrm{bc}}$ & $\begin{array}{l}1.51 .11 .01 \\
581.966^{\text {ab }}\end{array}$ & $747.78 \pm 136.72^{\mathrm{a}}$ & $411.05 \pm 79.05^{\mathrm{bc}}$ & $\begin{array}{l}551.68 \pm 26.02^{\mathrm{abc}} \\
\text { (1) }\end{array}$ & $621.5 \pm 163.03^{\text {ab }}$ & $\begin{array}{l}473.02 \pm 149.16^{\mathrm{bc}} \\
473.14\end{array}$ & $480.44 \pm 103.12^{\mathrm{bc}}$ & $656.32 \pm 239.05^{\text {ab }}$ \\
\hline Ethyl benzoate & $136.53 \pm 23.28^{\mathrm{a}}$ & $150.24 \pm 24.64^{4}$ & $75.98 \pm 14.76^{6}$ & $66.77 \pm 5.50^{\mathrm{bc}}$ & $62.87 \pm 5.25^{\text {bcd }}$ & $36.88 \pm 11.59^{\circ}$ & $40.90 \pm 4.17^{\mathrm{dc}}$ & $43.94 \pm 11.38^{\mathrm{de}}$ & $31.97 \pm 3.41^{\mathrm{c}}$ & $116.44 \pm 5.62^{\mathrm{c}}$ \\
\hline Diet & $1411.57 \pm 555.00^{\text {abced }}$ & $\pm+963.70^{\mathrm{a}}$ & $4 \pm 156.08^{\text {ab }}$ & $1495.28 \pm 85.56^{\text {abced }}$ & $1382.4 \pm 116.09^{\text {abcod }}$ & $1533.56 \pm 67.20^{\mathrm{abc}}$ & $1112.4 \pm 76.08^{\text {bed }}$ & $803.16 \pm 42.80^{\mathrm{d}}$ & $1348.05 \pm 127.54^{\text {abced }}$ & $1099.50 \pm 158.63^{\text {cd }}$ \\
\hline Ethyl 9-decenoate & $34.05 \pm 12.52^{\mathrm{ab}}$ & $34.64 \pm 19$ & $34.00 \pm 6$ & $34.75 \pm 2$ & $38.92 \pm 4.29^{\mathrm{a}}$ & $25.96 \pm 1.81^{\text {th }}$ & $\begin{array}{l}112.4 \pm / 0.08 \\
\text { n.d. }\end{array}$ & $20.79 \pm \pm 0.24^{\mathrm{b}}$ & $22.99 \pm 4.17^{\text {th }}$ & \\
\hline Methyl salicylate & $8.44 \pm 4.22^{\mathrm{d}}$ & $36.27 \pm 26.88^{\mathrm{b}}$ & $5.97 \pm 0.39^{\mathrm{d}}$ & $31.66 \pm 3.39^{\mathrm{bc}}$ & $6.78 \pm 1.62^{d}$ & $21.95 \pm 1.23^{\text {bed }}$ & $5.06 \pm 0.26^{d}$ & $63.40 \pm 6.97^{a}$ & $18.35 \pm 2.15^{\text {d }}$ & $11.36 \pm 2.35^{\mathrm{d}}$ \\
\hline Phenylethyl acetate & $64.21 \pm 14.60^{\mathrm{a}}$ & $56.34 \pm 8.14^{\mathrm{a}}$ & $57.50 \pm 3.50^{\mathrm{a}}$ & $39.30 \pm 2.49^{c}$ & $40.21 \pm 3.75^{\circ}$ & $38.85 \pm 5.14^{c}$ & $35.00 \pm 0.18^{c}$ & $54.89 \pm 5.35^{\text {ab }}$ & $44.02 \pm 3.79^{\mathrm{bc}}$ & $34.44 \pm 6.12^{c}$ \\
\hline Ethyl 3-phenylpropionate & $\begin{array}{l}04.21 \pm 1.00 \\
10.95 \pm 1.05^{\text {ab }}\end{array}$ & $\begin{array}{l}50.34 \pm 8.14 \\
17.04 \pm 11.15^{\mathrm{a}}\end{array}$ & $11.66 \pm 1.43^{\text {ab }}$ & $10.24 \pm 1.22^{\mathrm{ab}}$ & $10.70 \pm 2.13^{\text {ab }}$ & $\begin{array}{l}38.85 \pm 1.14 \\
9.62 \pm 1.04^{\mathrm{b}}\end{array}$ & & & & $\begin{array}{l}3.44 \pm 0.124^{\mathrm{b}} \\
8.24 \pm 1.24^{2}\end{array}$ \\
\hline Ethyl laurate & $2.00^{\text {ab }}$ & & $-4.80^{\text {ab }}$ & & & & & & $19.91 \pm$ & $33.00 \pm 2.89^{\text {ab }}$ \\
\hline Formic acid, $\mathrm{h}$ & & $17.77 \pm 1.06^{\mathrm{a}}$ & & $12.45 \pm 1.11^{\mathrm{b}}$ & $12.65 \pm 1.30^{\mathrm{b}}$ & $18.92 \pm 0.34^{\mathrm{a}}$ & $\begin{array}{l}1.40 \pm 25.83 \\
9.75 \pm 1.12^{\mathrm{c}}\end{array}$ & $18.04 \pm 1.01^{\mathrm{a}}$ & & 8 \\
\hline
\end{tabular}

The result expressed as mean value and standard deviations over three replications.

a, b, c, d, e, f, g, h, i, j Different letters in the same row indicate statistical differences at the 0.05 level according to Duncan test.

n.d., not detect. 
Esters, the most abundant aroma compounds in wine samples, are usually considered very important for positive aromas. Among all analysed vintages, wines of $2010\left(6279.00 \mu \mathrm{g} \mathrm{L}^{-1}\right)$ and $2011\left(6138.00 \mu \mathrm{g} \mathrm{L}^{-1}\right)$ had a significantly higher content $(\mathrm{p}<0.05)$ of total esters and other vintages ranged from 3997.77 to $5654.88 \mu \mathrm{g} \mathrm{L}^{-1}$. The esters detected in wines were usually categorized into two main groups: Fatty acid ethyl esters and acetate esters. Fatty acid ethyl esters, a large group of compounds in wines (Dzialo et al., 2017), were related to the fruity aroma. Ethyl octanoate accounted for a largest proportion varied from $1594.05 \mu \mathrm{g} \mathrm{\textrm {L } ^ { - 1 }}$ to $2197.70 \mu \mathrm{g} \mathrm{L}^{-1}$ among samples and vintage had no significant effect $(p>0.05)$ on this compound. Ethyl 2-methylbutyrate, ethyl isovalerate, ethyl 9-decenoate, octanoic acid, 3-methylbutyl ester and 2-hydroxypropanoic acid pentyl ester were not detected in 2018 suggesting that these compounds have not been formed in this harvest year. Another group of esters, acetate esters, are formed by the reaction of acetyl-CoA and higher alcohols (Sumby et al., 2010). The acetate esters appearing in all samples consisted of isoamyl, phenlethyl and bornyl acetates. The significantly higher concentration $(\mathrm{p}<0.05)$ of isoamyl acetate was detected in $2016\left(86.27 \mu \mathrm{g} \mathrm{L^{-1 }}\right)$ and $2015\left(81.01 \mu \mathrm{g} \mathrm{L}^{-1}\right)$. Phenylethyl acetate related to the typical "flower" or "rose" aroma were identified with higher content in 2008 but lower in 2017 showing that the formation of esters is closely related to storage time.

Benzene compounds were one of the most abundant compounds after esters (Table 3). These detected compounds also exist in previous reports (Sánchez-Palomo et al., 2019). Phenol, Benzyl alcohol, phenethyl alcohol and 2,4-di-tert-butylphenol existed in all samples, possibly enhancing the overall aroma of wine based on their concentration (Sánchez-Palomo et al., 2019). Benzyl alcohol presented the highest level among benzene compounds ranged from 1022.07 to $1060.50 \mu \mathrm{g} \mathrm{L}^{-1}$.

Alcohols, synthesized by yeast during the alcoholic fermentation, usually have strong and pungent odour characteristics (Dzialo et al., 2017). In general, regardless of the grape variety used in the winemaking process, the alcohol concentration produced by yeast was lower than $300 \mathrm{mg} \mathrm{L}^{-1}$. In this range, they can contribute to the desirable complexity of wine aroma. While at a higher concentration (> $400 \mathrm{mg} \mathrm{L}^{-1}$ ), they became negative aroma quality factors (Rapp and Versini, 1995). The total amounts of alcohols in our research was below $300 \mathrm{mg} \mathrm{L}^{-1}$ (47.43-2689.65 $\left.\mu \mathrm{g} \mathrm{L}^{-1}\right)$, which might explain the elegance aroma in wines of this region. 1-pentanol was significantly higher $(\mathrm{p}<0.05)$ in wines of 2008, 2010, 2012, 2014, 2015 compared with other vintages, accounted for 96.15 to $98.77 \%$ on total alcohols. This was responsible for the higher content of total alcohol in these harvests.

Three fatty acids were detected in samples, which were usually associated with fatty, cheese-like and spoilage aroma notes. The concentration of fatty acid was in agreement with those found by Ayestaran et al. in red wines made from other varieties (Shinohara, 1985). The total fatty acids ranged from 75.66 to $258.48 \mu \mathrm{g}$ $\mathrm{L}^{-1}$. Decanoic acid showed no statistical differences in four consecutive vintages from 2009 to 2012 vintage, with the highest content in $2017\left(28.84 \mu \mathrm{g} \mathrm{L}^{-1}\right)$ and lowest in $2008\left(5.00 \mu \mathrm{g} \mathrm{L}^{-1}\right)$.

Terpenes and C13-norisoprenoids compounds are typical varietal aroma. Five terpenes and C13norisoprenoids compounds were detected. $\beta$-Damascenone, a key compound, usually related to wines' floral aroma due to its low odour threshold (Guth, 1997). It appeared at the highest value in 2008 with $8.52 \mu \mathrm{g} \mathrm{L}^{-1}$ and the lowest in 2017 with $5.58 \mu \mathrm{g} \mathrm{L}^{-1}$. This result might be related to the high acidity of the 2008 vintage wine sample because $\mathrm{C}_{13}$-norisoprenoids compounds came from the enzymatic or acid hydrolysis of carotenoids. Vintage showed statistically significant effect on this compound.

\section{Principal Component Analysis between Volatile Compounds and Vintages}

PCA was employed to establish correlations between the vintages and the volatile compounds. The aim was to visualize the differences/similarities among Cabernet Sauvignon wines and establish a possible relationship among volatile compounds and vintage. Figure 2 showed a PCA biplot of the first two Principal Components (PCs), which explained $78 \%$ of the total variance. The distribution of date was accumulated three groups according to PCA. The first axis (PC1), with $56 \%$ of the variance explained. Whereas, the second axis (PC2), with $22 \%$ of the variance explained. 2-hexenoic acid, ethyl ester (Z6), n-heptanol (HJ2), bornyl acetate (Z11), ethyl isopentyl succinate (Z22) and terpinen-4-ol (YW3) located in PC1 positive were the main compounds responsible for classification according to 2017 vintage. In contrast, the wines of earlier vintages of 2008 and 2009 projected in PC1 negative, were mainly characterized by ethyl 3-phenylpropionate (Z19), ethyl laurate (Z20), ethyl nonanoate (Z10), ethyl 2methylbutyrate(Z2), ethyl isovalerate (Z3), phenethyl acetate (Z18), propanoic acid and 2-hydroxy-pentyl ester(Z24). PC2 positive contributed to the distinction of samples from 2010-2016 vintage according to formic acid, heptyl ester (Z21), methyl salicylate (Z17), benzyl alcohol (B1), octanoic acid (S2), 1-nonanol (HJ1), methyl n-caprate (Z12). 


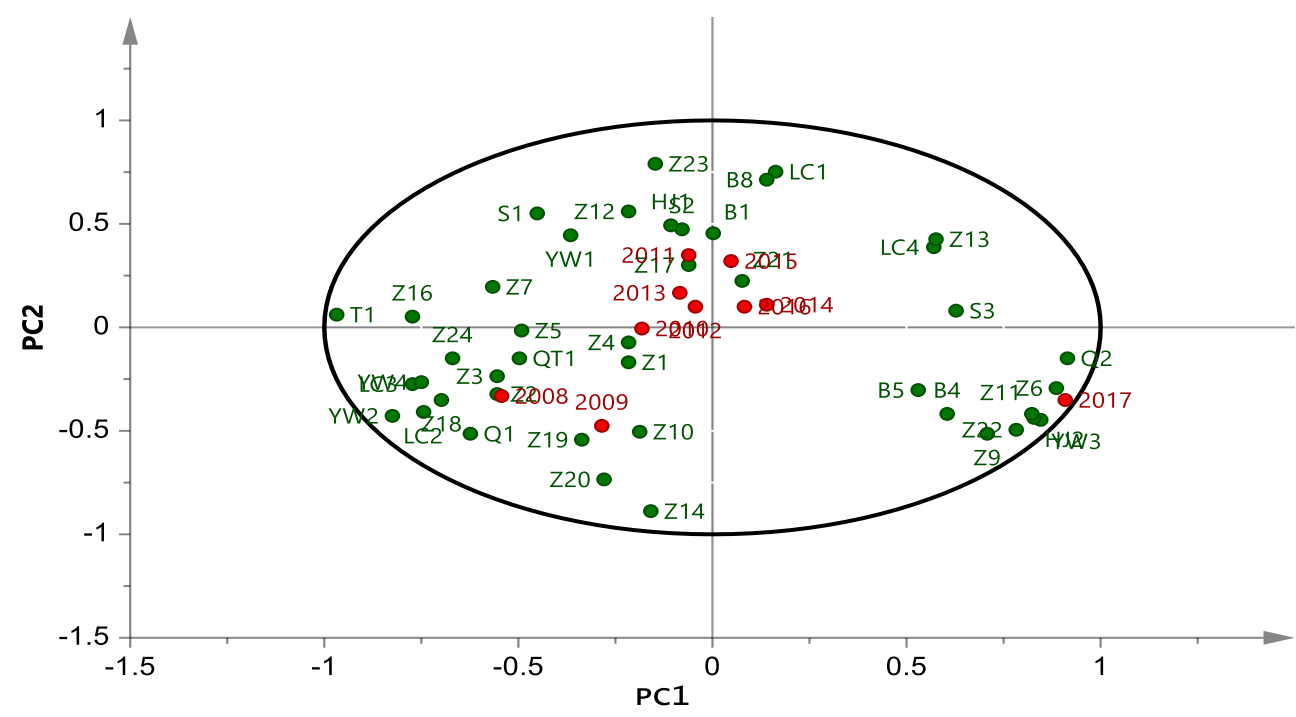

Fig. 2: Results from PCA analysis on the first two principal components. (•projection of the samples; $\bullet$ factor loadings of variables; LC1: 1-Hexanol; LC2: (E)-3-hexen-1-ol; LC3: (Z)-3-hexen-1-ol; LC4: (E)-4-hexen-1-ol; YW1: 4-terpineol; YW2: L- alpha. -terpineol; YW3: Terpinen-4-ol; YW4: $\beta$-damascenone; B1: Benzyl alcohol; B4: 2,4-di-tert-butylphenol; B5: phenylethylene; B8: Benzaldehyde; Q1: 1-nonanol; S1: Hexanoic acid; S2: Octanoic acid; S3: Decanoic acid; HJ1: 1nonanol; HJ2: n-heptanol; Z1: Ethyl butyrate; Z2: Ethyl 2-methylbutyrate; Z3: Ethyl isovalerate; Z4: Isoamyl acetate; Z5: Ethyl hexanoate; Z6: 2-hexenoic acid, ethyl ester; Z7: Methyl octanoate; Z9: Isopentyl hexanoate; Z10: Ethyl nonanoate; Z11: Bornyl acetate; Z12: Methyl n-caprate; Z13: Ethyl caprate; Z14: Ethyl benzoate; Z16: Ethyl 9-decenoate; Z17: Methyl salicylate; Z18: Phenylethyl acetate; Z19: Ethyl 3-phenylpropionate; Z20: Ethyl laurate; Z21: Formic acid, heptyl ester; Z22: ethyl isopentyl succinate; Z23: Octanoic acid, 3-methylbutyl ester; Z24: 2-hydroxy-propanoic acid pentyl ester)

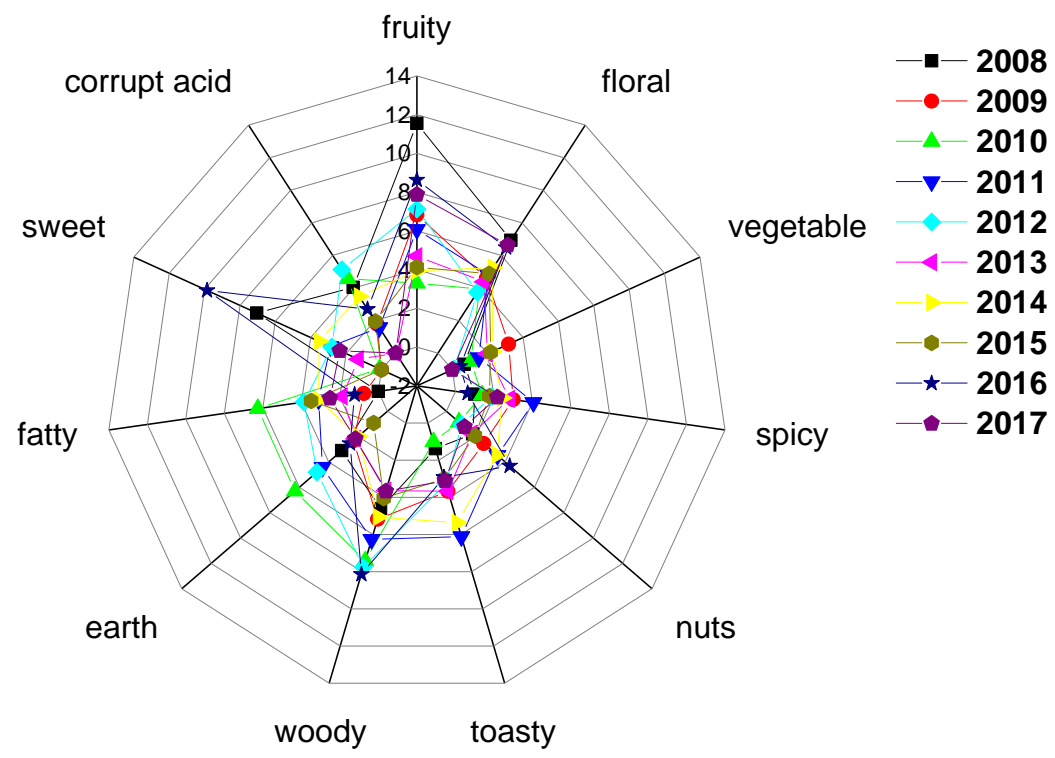

Fig. 3: Radar map obtained by scoring the aromatic series of Cabernet Sauvignon wines of ten successive vintages

\section{Sensory Evaluation of Wines}

The aroma attributes of different vintages were described according 11 representative odorant notes by a radar-web (Fig. 3), since it is impossible to evaluate the overall aroma solely on the basis of perceived sum of individual compounds. As could be seen some variations of sensory notes were detected among all studied vintages. The Cabernet Sauvignon wines of 2008 showed higher intensity of fruit (11.55) and sweet 
aromas (7.05). The scores of fruit and floral notes in 2009 and 2017 vintages were higher than other odorant notes. In the vintage of 2010 , the earth, fatty and woody odour were more intense compared to other descriptors. The wine of 2011 was more pronounced by fruit, toasty and woody notes. The overall aroma was balanced in vintage of 2013, 2014 and 2015 vintages according to panelist. Floral (5.25) and toasty (5.36) notes were more intense in 2014 but still lower than 2011. Compared with other aroma notes, the wine of 2015 showed a highest score of floral notes (4.88), but the overall aroma intensity was weak. According to the panelists, the 2016 vintage presented a strong plum taste that may be due to higher intensity of sweet.

\section{Conclusion}

A comprehensive study of the bioactive compounds associated with health and sensory profiles of Cabernet Sauvignon wines of different vintages have been obtained. The study provided an interesting insight, on the impact of vintages in final quality and therefore in its market value. The wine of different vintages continued to be significantly different. Malic acid, lactic acid and tartaric acid were the main organic acid among all samples. The earlier vintages (2008-2009) appeared at higher content of total organic acids. The latest vintages of 2016 and 2017 showed higher concentration of tartaric acid, ferulic acid and total phenolics. These results indicated that phenolic and organic acid might provide a suitable tool for classification of Huailai wines by vintages. Regarding to volatile compounds, 2hexenoic acid, ethyl ester, n-heptanol, bornyl acetate, ethyl isopentyl succinate and terpinen-4-ol were the main compounds responsible for classification according to 2017 vintage. The wines of 2010 to 2016 were characterized by formic acid, heptyl ester, methyl salicylate, benzyl alcohol, octanoic acid, 1-nonanol, methyl n-caprate. Whereas the wines of earlier vintages of 2008 and 2009 were mainly characterized by ethyl 3phenylpropionate, ethyl laurate, ethyl nonanoate, ethyl 2methylbutyrate, ethyl isovalerate, phenethyl acetate, propanoic acid and 2-hydroxy-pentyl ester. According to sensory profiles, the middle vintages (2013-2015) showed the balanced aroma might related to these volatile compounds including formic acid, heptyl ester, methyl salicylate, benzyl alcohol, octanoic acid. In this research, a lot of chemical compositions of Cabernet Sauvignon wines were conducted. Whereas the mechanism of component transformation such as phenolics is expected to study along with the storage period extends. The knowledge of chemical indices in Cabernet Sauvignon wines of different harvests is of great interest for wines producer, providing useful information to consumers' choice.

\section{Funding Information}

This work was financially supported by the National Natural Science Foundation, China (Grant No. 31601462), the Fundamental Research Funds for Henan Key Laboratory of Industrial Microbial Resources and Fermentation Technology, Open Foundation, China, Nanyang, (Grant No. IMRFT20180308) and Science and Technology Research Project of Hebei Province (Grant No. BJ2017016).

\section{Author's Contributions}

Yufeng Ding and Yanli Ma: Has contributed in the experiment, paper writing and publication.

Suping Li, Jingjing Liang and Xiaoli Xi: Have assisted in the experiment.

Jie Wang, Jianfeng Sun, Haiyan Yu and Shuxian Guo: Has reviewed and revised the manuscript.

\section{Ethics}

There are not any ethical issues to declare that could arise after the publication of this manuscript. The authors declare that they have no competing interests.

\section{References}

Artero, A., Artero, A., Tarín, J. J., \& Cano, A. (2015). The impact of moderate wine consumption on health. Maturitas, 80(1), 3-13.

Aubert, C., \& Chalot, G. (2018). Chemical composition, bioactive compounds and volatiles of six table grape varieties (Vitis vinifera L.). Food chemistry, 240, 524-533.

Burin, V. M., Costa, L. L. F., Rosier, J. P., \& BordignonLuiz, M. T. (2011). Cabernet Sauvignon wines from two different clones, characterization and evolution during bottle ageing. LWT-Food Science and Technology, 44(9), 1931-1938.

Cai, J., Zhu, B. Q., Wang, Y. H., Lu, L., Lan, Y. B., Reeves, M. J., \& Duan, C. Q. (2014). Influence of pre-fermentation cold maceration treatment on aroma compounds of Cabernet Sauvignon wines fermented in different industrial scale fermenters. Food chemistry, 154, 217-229.

Canas, S., Caldeira, I., Anjos, O., \& Belchior, A. P. (2019). Phenolic profile and colour acquired by the wine spirit in the beginning of ageing: Alternative technology using micro-oxygenation vs traditional technology. LWT, 111, 260-269.

Chidi, B. S., Rossouw, D., Buica, A. S., \& Bauer, F. F. (2015). Determining the impact of industrial wine yeast strains on organic acid production under white and red wine-like fermentation conditions. South African Journal of Enology and Viticulture, 36(3), 316-327. 
Colangelo, D., Torchio, F., De Faveri, D. M., \& Lambri, M. (2018). The use of chitosan as alternative to bentonite for wine fining: Effects on heat-stability, proteins, organic acids, colour and volatile compounds in an aromatic white wine. Food chemistry, 264, 301-309.

de Esteban, M. L. G., Ubeda, C., Heredia, F. J., Catania, A. A., Assof, M. V., Fanzone, M. L., \& Jofre, V. P. (2019). Impact of closure type and storage temperature on chemical and sensory composition of Malbec wines (Mendoza, Argentina) during aging in bottle. Food Research International, 125, 108553.

Dumitriu, G. D., de Lerma, N. L., Zamfir, C. I., Cotea, V. V., \& Peinado, R. A. (2017). Volatile and phenolic composition of red wines subjected to aging in oak cask of different toast degree during two periods of time. LWT, 86, 643-651.

Dzialo, M. C., Park, R., Steensels, J., Lievens, B., \& Verstrepen, K. J. (2017). Physiology, ecology and industrial applications of aroma formation in yeast. FEMS microbiology reviews, 41(Supp_1), S95-S128.

Erkan, S. B., Gürler, H. N., Bilgin, D. G., Germec, M., \& Turhan, I. (2020). Production and characterization of tempehs from different sources of legume by Rhizopus oligosporus. LWT, 119, 108880.

Fanzone, M., Peña-Neira, A., Gil, M., Jofré, V., Assof, M., \& Zamora, F. (2012). Impact of phenolic and polysaccharidic composition on commercial value of Argentinean Malbec and Cabernet Sauvignon wines. Food Research International, 45(1), 402-414.

Folin, O., \& Denis, W. (1915). A colorimetric method for the determination of phenols (and phenol derivatives) in urine. Journal of Biological Chemistry, 22(2), 305-308.

Forester, S. C., \& Waterhouse, A. L. (2009). Metabolites are key to understanding health effects of wine polyphenolics. The Journal of nutrition, 139(9), $1824 \mathrm{~S}-1831 \mathrm{~S}$.

GB/T 15038-2006, 2006. Analytical methods of wine and fruit wine. https://www.winesofchile.org/wpcontent/uploads/2018/08/GB_15037-

2006_National_Standard_of_the_People_s_Republi c_of_China_Wines-2.pdf

Glories, Y. (1984). La couleur des vins rouges: 2e. Partie: mesure, origine et interpretation. Connaissance de la Vigne et du Vin, 18.

Guth, H. (1997). Quantitation and sensory studies of character impact odorants of different white wine varieties. Journal of Agricultural and Food Chemistry, 45(8), 3027-3032.

Han, Y., Du, J., Li, J., \& Li, M. (2019). Quantification of the Organic Acids in Hawthorn Wine: A Comparison of Two HPLC Methods. Molecules, 24(11), 2150.
Hernanz, D., Gallo, V., Recamales, Á. F., MeléndezMartínez, A. J., González-Miret, M. L., \& Heredia, F. J. (2009). Effect of storage on the phenolic content, volatile composition and colour of white wines from the varieties Zalema and Colombard. Food Chemistry, 113(2), 530-537.

Jiang, B., Xi, Z., Luo, M., \& Zhang, Z. (2013). Comparison on aroma compounds in Cabernet Sauvignon and Merlot wines from four wine grapegrowing regions in China. Food research international, 51(2), 482-489.

Katalinić, V., Možina, S. S., Skroza, D., Generalić, I., Abramovič, H., Miloš, M., ... \& Boban, M. (2010). Polyphenolic profile, antioxidant properties and antimicrobial activity of grape skin extracts of 14 Vitis vinifera varieties grown in Dalmatia (Croatia). Food chemistry, 119(2), 715-723.

Li, H., Wang, X., Li, Y., Li, P., \& Wang, H. (2009). Polyphenolic compounds and antioxidant properties of selected China wines. Food chemistry, 112(2), 454-460.

Li, Z., Pan, Q., Jin, Z., Mu, L., \& Duan, C. (2011). Comparison on phenolic compounds in Vitis vinifera cv. Cabernet Sauvignon wines from five wine-growing regions in China. Food Chemistry, 125(1), 77-83.

McRae, J. M., Dambergs, R. G., Kassara, S., Parker, M., Jeffery, D. W., Herderich, M. J., \& Smith, P. A. (2012). Phenolic compositions of 50 and 30 year sequences of Australian red wines: The impact of wine age. Journal of agricultural and food chemistry, 60(40), 10093-10102.

Miller, G. L. (1959). Use of dinitrosalicylic acid reagent for determination of reducing sugar. Analytical chemistry, 31(3), 426-428.

Nevares, I., \& del Álamo, M. (2008). Measurement of dissolved oxygen during red wines tank aging with chips and micro-oxygenation. Analytica chimica acta, 621(1), 68-78.

Perestrelo, R., Bordiga, M., Locatelli, M., Silva, C., \& Câmara, J. S. (2020). Polyphenols, biogenic amines and amino acids patterns in Verdelho wines according to vintage. Microchemical Journal, 153, 104383.

Peri, P., Kamiloglu, S., Capanoglu, E., \& Ozcelik, B. (2015). Investigating the Effect of Aging on the Phenolic Content, Antioxidant Activity and Anthocyanins in Turkish Wines. Journal of Food Processing and Preservation, 39(6), 1845-1853.

Rapp, A., \& Versini, G. (1995). Influence of nitrogen compounds in grapes on aroma compounds of wines. In Developments in food science (Vol. 37, pp. 1659-1694). Elsevier. 
Robles, A., Fabjanowicz, M., Chmiel, T., \& PłotkaWasylka, J. (2019). Determination and identification of organic acids in wine samples. Problems and challenges. TrAC Trends in Analytical Chemistry, $120,115630$.

Samoticha, J., Wojdyło, A., Chmielewska, J., Politowicz, J., \& Szumny, A. (2017). The effects of enzymatic pre-treatment and type of yeast on chemical properties of white wine. LWT-Food Science and Technology, 79, 445-453.

Sánchez-Palomo, E., Delgado, J. A., Ferrer, M. A., \& Viñas, M. G. (2019). The aroma of La Mancha Chelva wines: Chemical and sensory characterization. Food Research International, 119, 135-142.

Sartor, S., Toaldo, I. M., Panceri, C. P., Caliari, V., Luna, A. S., de Gois, J. S., \& Bordignon-Luiz, M. T. (2019). Changes in organic acids, polyphenolic and elemental composition of rosé sparkling wines treated with mannoproteins during over-lees aging. Food Research International, 124, 34-42.

Schelezki, O. J., Šuklje, K., Boss, P. K., \& Jeffery, D. W. (2018). Comparison of consecutive harvests versus blending treatments to produce lower alcohol wines from Cabernet Sauvignon grapes: Impact on wine volatile composition and sensory properties. Food chemistry, 259, 196-206.

Shinohara, T. (1985). Gas chromatographic analysis of volatile fatty acids in wines. Agricultural and Biological Chemistry, 49(7), 2211-2212.
Sumby, K. M., Grbin, P. R., \& Jiranek, V. (2010). Microbial modulation of aromatic esters in wine: Current knowledge and future prospects. Food Chemistry, 121(1), 1-16.

Van Leeuw, R., Kevers, C., Pincemail, J., Defraigne, J. O., \& Dommes, J. (2014). Antioxidant capacity and phenolic composition of red wines from various grape varieties: Specificity of Pinot Noir. Journal of Food Composition and Analysis, 36(1-2), 40-50.

Wang, M. L., Wang, J. T., \& Choong, Y. M. (2004). Simultaneous quantification of methanol and ethanol in alcoholic beverage using a rapid gas chromatographic method coupling with dual internal standards. Food chemistry, 86(4), 609-615.

Xu, X. Q., Liu, B., Zhu, B. Q., Lan, Y. B., Gao, Y., Wang, D., ... \& Duan, C. Q. (2015). Differences in volatile profiles of Cabernet Sauvignon grapes grown in two distinct regions of China and their responses to weather conditions. Plant Physiology and Biochemistry, 89, 123-133.

Yang, B., Yao, H., Zhang, J., Li, Y., Ju, Y., Zhao, X., ... \& Fang, Y. (2020). Effect of regulated deficit irrigation on the content of soluble sugars, organic acids and endogenous hormones in Cabernet Sauvignon in the Ningxia region of China. Food Chemistry, 312, 126020. 